DOWNSTREAM EFFECTS OF RESERVOIR RELEASES TO THE

POTOMAC RIVER FROM LUKR, MARYLAND, TO

WASHINGTON, D.C.

By Thomas J. Trombley

U.S. GEOLOGICAL SURVEY

Water-Resources Investigations Report 82-4062

Prepared in cooperation with the

O.S. ARMY CORPS OF ENGINEERS

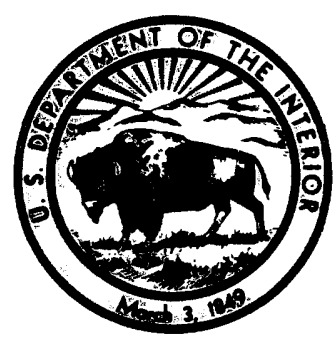

Towson, Mary land

Augus t 1982 


\section{UNITED STATES DEPARTMENT OF THE INTERIOR}

JAMES G. WATT, Secretary

GEOLOGICAL SURVEY

Dallas L. Peck, Di rector

For additional information write to:

District Chief

U.S. Geological Survey 208 Carroll Building 8600 La Salle Road

Tows on, Maryland 21204
Copies of this report can be purchased from:

Open-File Services Section Western Distribution Branch U.S. Geological Survey Box 25425, Federal Center Lakewood, Colorado 80225

(Telephone: (303) 234-5888) 


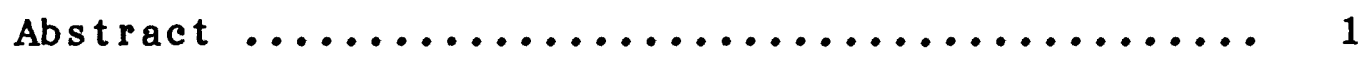

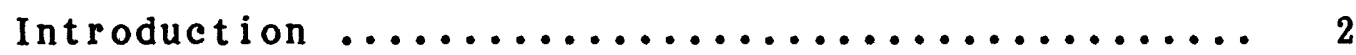

Background ........................ 2

Purpose and scope $\ldots \ldots \ldots \ldots \ldots \ldots \ldots \ldots \ldots, 4$

Modeling approach $\ldots \ldots \ldots \ldots \ldots \ldots \ldots \ldots \ldots \ldots \ldots \ldots$

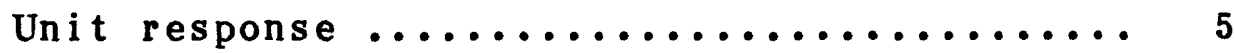

Hydrologic input data ................ 9

Subreach models ....................... 10

Luke to Cumberland calibration ........... 11

Summary of subreach results ............ 22

Linked model ......................... 25

Unit response to reservoir releases $\ldots \ldots \ldots \ldots \ldots \ldots 31$

Conclusions ......................... 35

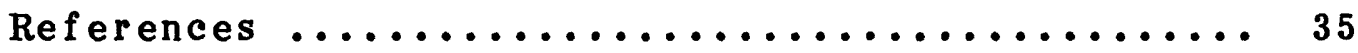


Page

Figure 1. Map showing location of study area and gaging stations used to model

streamf $10 w \ldots \ldots \ldots \ldots \ldots \ldots . \ldots \ldots$

2. Diagram showing development of the unit-response function .......... 6

3. Diagram showing application of the unit-response function to an input hydrograph to simulate the downstream response ................... 7

4. Map showing Potomac River bas in upstream from Cumberland, Md. ..... 12

5-8. Hydrographs of observed and simulated

flow and modeling errors at

Cumberland, Md., for the

$$
\begin{array}{llll}
\text { 5. } & 1952 \text { water year } \ldots \ldots \ldots \ldots \ldots \ldots & 15 \\
6 . & 1960 \text { water year } \ldots \ldots \ldots \ldots \ldots \ldots \ldots & 16 \\
7 . & 1966 \text { water year } \ldots \ldots \ldots \ldots \ldots \ldots \ldots & 17 \\
\text { 8. } & 1972 \text { water year } \ldots \ldots \ldots \ldots \ldots \ldots \ldots & 18
\end{array}
$$

9-12. Hydrographs of observed and simulated flows and modeling errors at Washington, D.C., using the linked model for the

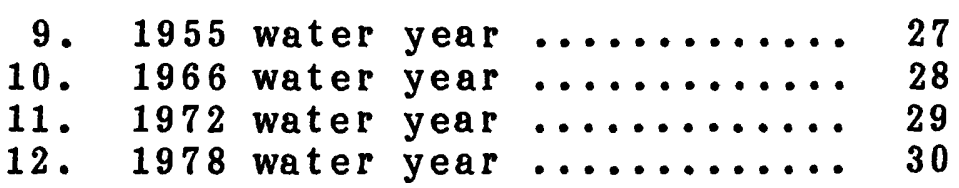

13. Graph showing the response at Washington, D.C., to a 3-day unit input at Luke, Md., using a 12-hour routing interval ..................... 33

14. Graph showing the response at downstream stations to a 7-day unit input at Luke, Md. 
Page

Table 1. Gaging stations used in modeling

2. Initial values for modeling parameters

3. Annual summary of modeling errors

(percent) for the Luke to

Cumber land, Md., subreach ........ 20

4. Distribution of daily error with

discharge for Luke to Cumberland,

Md., subreach model ............ 21

5. Subreach model summary ............ 23

6. Summary of modeling errors (percent)

for subreach models ............ 24

7. Summary of daily errors for subreach models .................... 25

8. Summary of modeling errors (percent) for the linked model (Luke, Md., to Washington, D.C.) ............... 26

9. Daily routing coefficients for linked model ..................... 32

10. Twelve-hour routing coefficients for 1 inked model ............... 32

11. Weekly routing coefficients for 1 inked $\operatorname{model} \ldots \ldots \ldots \ldots \ldots \ldots \ldots \ldots . . \ldots \ldots$ 
For those readers who may prefer to use metric units instead of inch-pound units, the conversion factors for units used in this report are listed below.

To convert from

foot $(f t)$

square foot per second

$$
\left(\mathrm{ft}^{2} / \mathrm{s}\right)
$$

cubic foot per second

$$
\left(\mathrm{ft}^{3} / \mathrm{s}\right)
$$

mile (mi)

square mile

$\left(\mathrm{mi}^{2}\right)$
Multiply by $\quad$ To obtain

0.3048 meter (m)

0.0929 square meter per second

$$
\left(\mathrm{m}^{2} / \mathrm{s}\right)
$$

0.02832 cubic meter per second

$$
\left(\mathrm{m}^{3} / \mathrm{s}\right)
$$

1.609

ki lomet er $(\mathrm{km})$

2.590

square kilometer

$\left(\mathrm{km}^{2}\right)$ 


\title{
DOWNSTREAM EFFECTS OF RESERVOIR RELEASES TO THE \\ POTOMAC RIVER FROM LUKE, MARYLAND, TO \\ MASHINGTON, D.C.
}

by Thomas J. Trombley

\begin{abstract}
A digital computer flow-routing model was used to determine the downstream effects on the Potomac River of flow releases from the Bloomington and Savage River Reservoirs. Both reservoirs are located upstream from Luke, Maryland, approximately $230 \mathrm{miles}$ upstream from Washington, D.C.

The downstream ef fects of reservoir releases were determined by using the unit-response method of flow routing implemented by a diffusion analogy. Results are in the form of unitresponse coefficients which are used to route flows downstream from Luke, Maryland.

A 24-hour sustained reservoir release input at Luke will result in 35 percent of the flow arriving at Washington, D.C., during the fourth day after the beginning of the release, followed by 61 percent and 4 percent arriving on the fifth and sixth days, respectively. For a 7-day sustained reservoir release, 47 percent of the flow will arrive during the first week and 53 percent will arrive during the second week.
\end{abstract}




\section{INTRODUCTION}

\section{Background}

The Potomac River basin ( $f$ ig. 1) has a drainage area of $11,560 \mathrm{mi}^{2}$ upstream from the gaging station near Washington, D.C. (station 01646500). Mean daily discharge (adjusted for diversions) at that gaging station was $11,490 \mathrm{ft}^{3} / \mathrm{s}$ for the period March 1930 through September 1980. A mean daily diversion of approximately $500 \mathrm{ft}^{3} / \mathrm{s}$ provides over 60 percent of the water supply for the Washington metropolitan area. These diversions are less than 5 percent of the mean daily flow.

The lowest observed streamflow at Washington, D.C., (adjusted for diversions) occurred in $1966 \mathrm{with} 610$ and $601 \mathrm{ft}^{3} / \mathrm{s}$ observed on september 9 and 10 , respectively. Diversions for those 2 days were 489 and $449 \mathrm{ft}^{3} / \mathrm{s}$, which is approximately three-fourths of the total flow. Obviously, if water-supply demands should increase and/or more severe droughts should occur, it may be impossible to satisfy the demands with the available streamflow. In addition, the remaining streamflow may not be adequate to prevent water-quality problems from developing downstream from Washington. To augment streamflow at Washington during low flow periods, the Bloomington Reservoir on the Potomac River and the Savage Reservoir on the Savage River are available. Both reservoirs are located upstream from Luke, Md., about $230 \mathrm{mi}$ upstream from Washington (see fig. 1 ). 


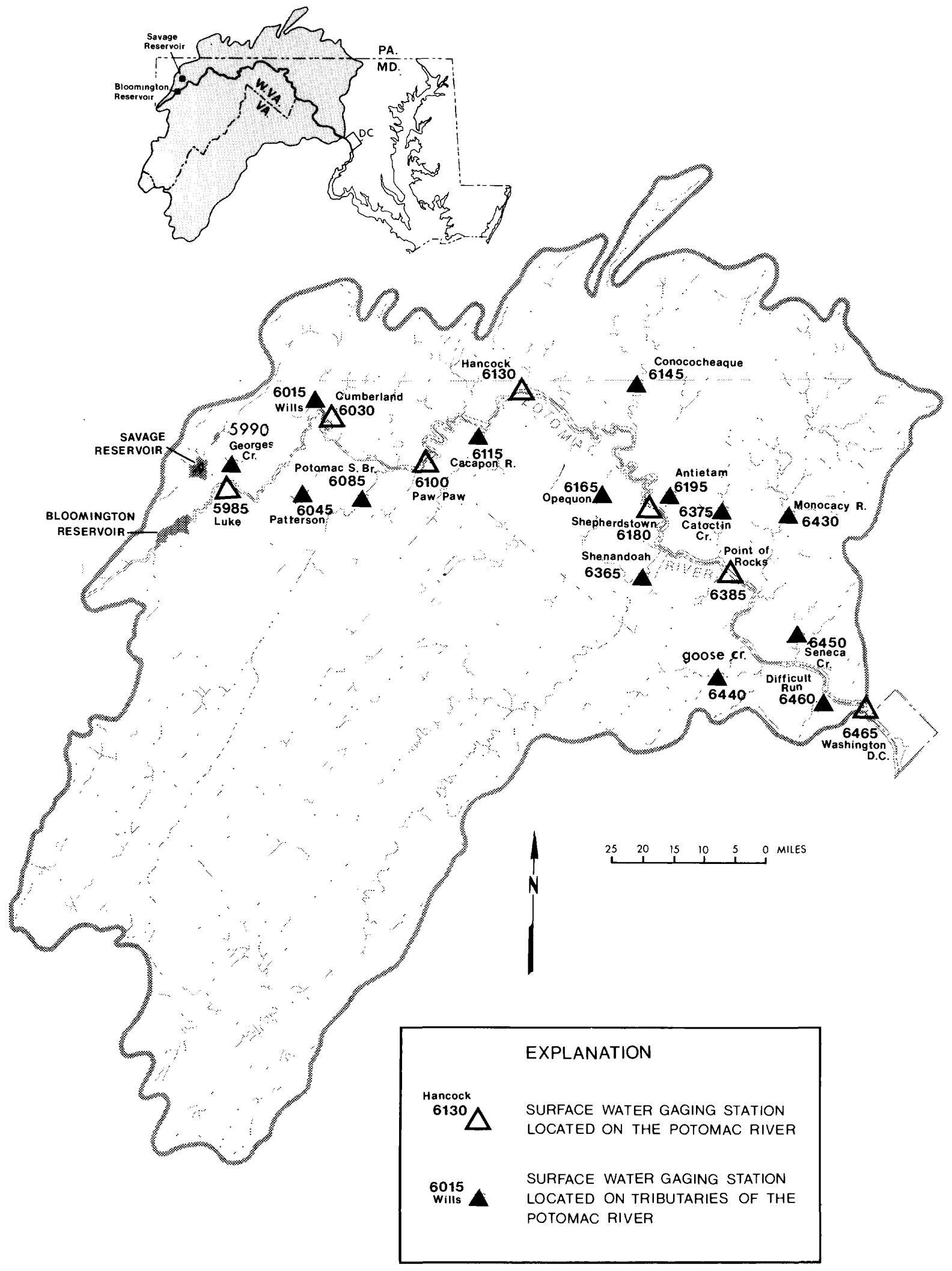

Figure 1.-- Location of study area and ganging stations used to model streamflow.

3 


\section{Purpose_and_Scope}

This report describes a method of estimating downstream responses of reservoir releases from the Bloomington and savage Reservoirs in the upper Potomac River basin. A flow-routing model is used to route reservoir releases down the river to Washington, D.C. The model yields unit-response coefficients that provide a simple method of estimating the time at which unit releases from the reservoirs will arrive at each of the following downstream stations:

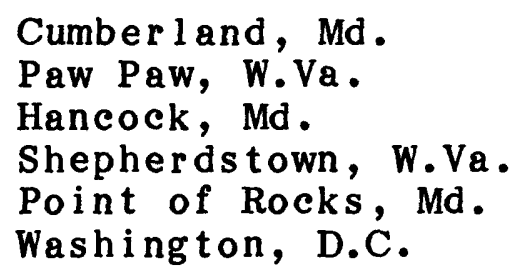

This study was conducted by the U.S. Geological Survey, in cooperation with the U.S. Army Corps of Engineers, Baltimore District. 


\section{MODELING APPROACH}

A flow-routing model was applied to six subreaches on the Potomac River using the unit-response method. The subreach models were then calibrated and linked together to produce a final model. The computer program used to model streamflow was developed by J. O. Shearman, Gloria Stiltner, and W. H. Doyle, Jr. (Shearman, 1980, written commun.).

\section{Unit Response}

Streamflow was modeled using the unit-response method of flow routing (Sauer, 1973). Unit response is defined as the downstream response to a unit flow input at the upstream end of the reach (fig. 2). It is analagous to the unit-hydrograph method of surface runoff. In this method, a unit-response function in the form of daily routing coefficients is applied to the input flow at the upstream end of the reach to route that flow to the downstream end of the reach (fig. 3 ). The discrete equa$t i o n$ for the unit-response method of flow routing is:

$$
y_{t}=\sum_{k=0}^{\infty} \nabla_{k} x_{(t-k)}
$$

where

$$
\begin{aligned}
y_{t} & =\text { outflow at time }(t) ; \\
x_{(t-k)} & =\text { inflow at time }(t-k) ; \text { and } \\
U_{k} & =\text { unit response coefficient for lag }(k) .
\end{aligned}
$$

Any ungaged intervening flow or other gains or losses must be explicitly accounted for and added to, or subtracted from the routed flow. 


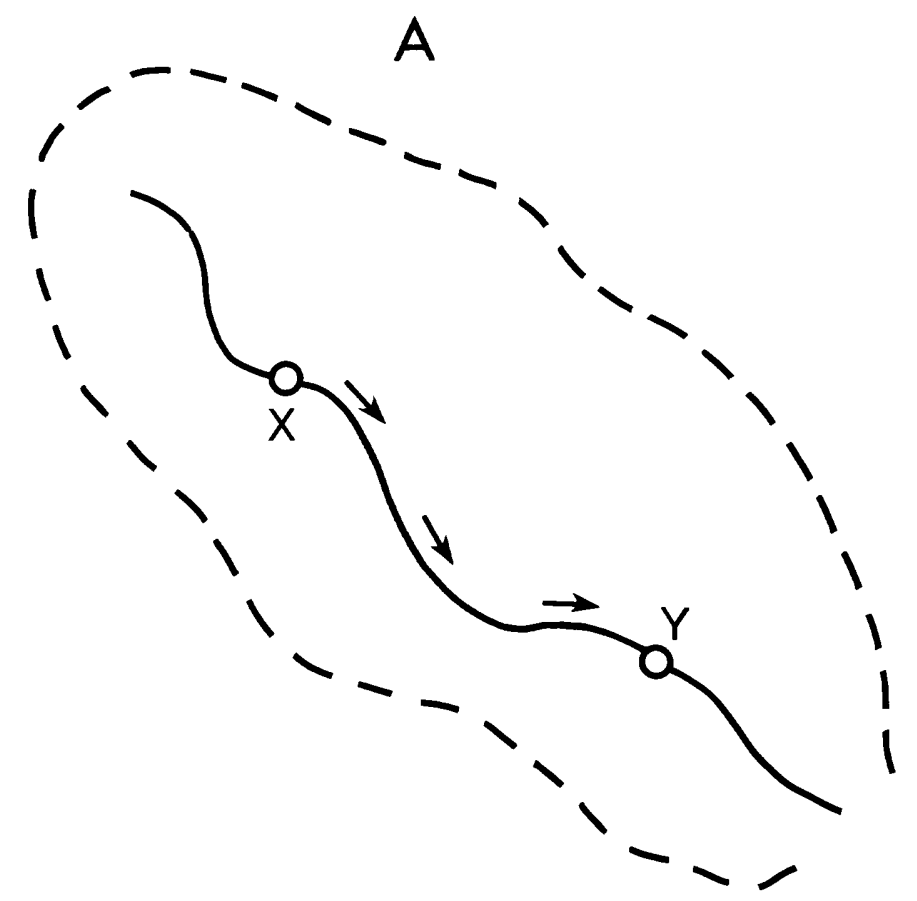
A. Hypothetical drainage basin
showing reach $X-Y$.

B

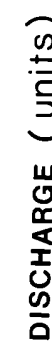

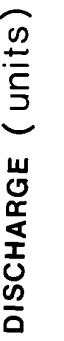

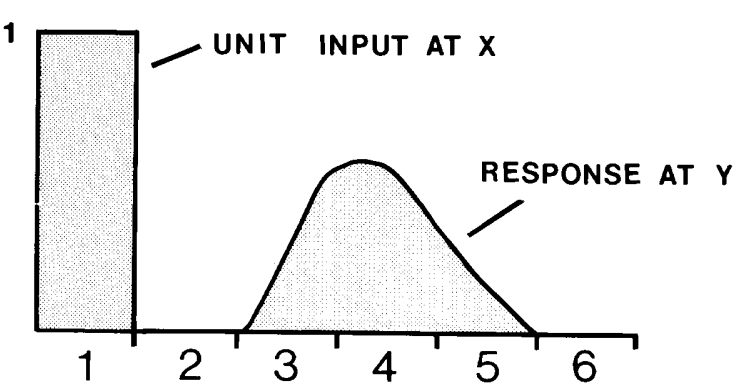

B. Unit flow input at $x$ with unit duration, analog unit response function shows the Instantaneous flow at $Y$.

TIME ( units )

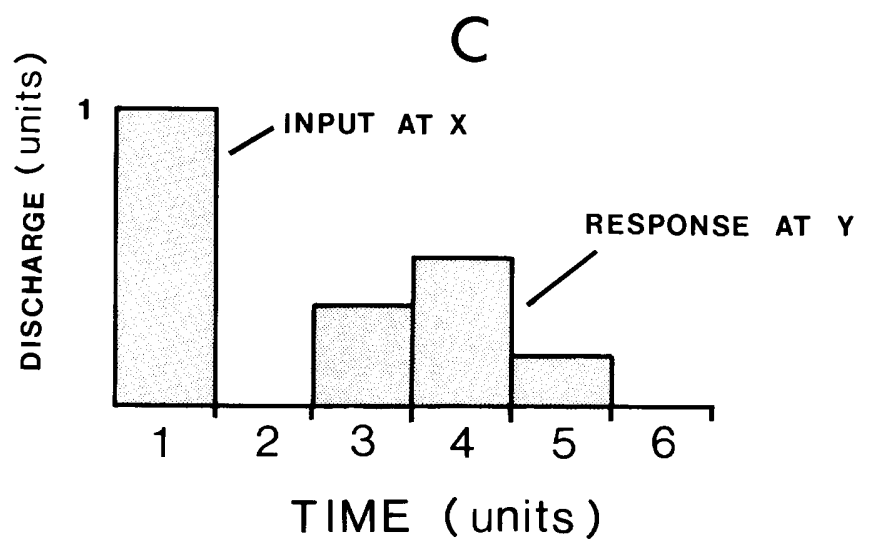

C. Same unit input at $X$, but unit response functions in terms of flow/ unit time.

Figure 2.-- Development of the unit - response function. 


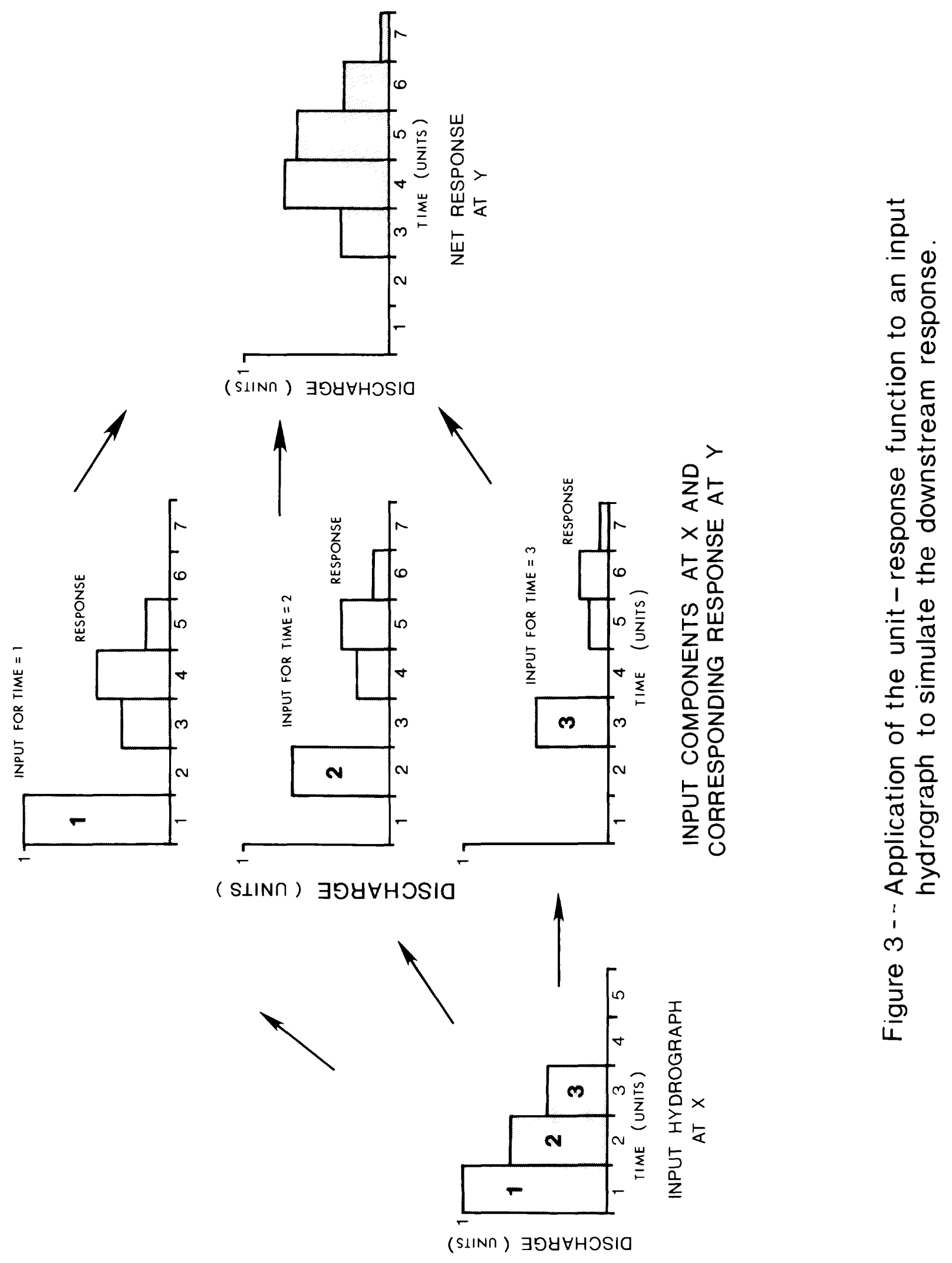


Unit-response functions were calculated using the diffusion approximation to the dynamic equations of open-channel flow (Keefer and McQuivey, 1974). This approximation describes the flow in terms of an input pulse that travels down the channel, spreading out or diffusing as it travels. Three parameters are needed to apply the diffusion analogy:

1.) Wave dispersion (K), which defines damping of the wave or flow pulse as it moves downstream,

$$
K=\frac{\mathbf{Q}}{(2 \mathrm{SW})}
$$

where

$$
\begin{aligned}
& Q=\text { reference discharge in } \mathrm{ft}^{3} / \mathrm{s} \text {; } \\
& \mathbf{S}=\text { average surface slope at } Q ; \text { and } \\
& W=\text { average channel width at } Q \text {. }
\end{aligned}
$$

2.) Wave celerity (C), which is the downstream velocity of the wave,

$$
C=\frac{1}{W} \frac{d Q}{d y}
$$

where

$$
\frac{d Q}{d y}=\text { slope of discharge/stage at } Q \text {. }
$$

3.) Reach length (X), which is the distance, in miles, that the flow has to travel.

The method used in this study combines system inputs with a unit-response function to produce a system output. In the final linked model, system input is the streamflow at Luke plus gaged tributary inflows, and inflows from ungaged areas between Luke and Washington, D.C. The unit-response function is a series of routing coefficients which convey daily flows through the system from Luke to Washington, D.C, and to intermediate points, with proper accounting for traveltime and dispersion. The system output is the total streamflow at Washington, D.C., and at the intermediate points. This model treats the system as if the unit-response is independent of discharge. That is, the response is the same for all flows. 
Streamflow records from 7 mainstem Potomac River gaging stations and 16 tributary gaging stations were used in the modeling process. Table 1 lists the station numbers, names, and drainage areas above the stations as well as the water years for which flow data were used for model calibration. The locations of these gaging stations within the Potomac River basin are shown in $f$ igure 1.

Table 1. -- Geging statlons usod In modelling process

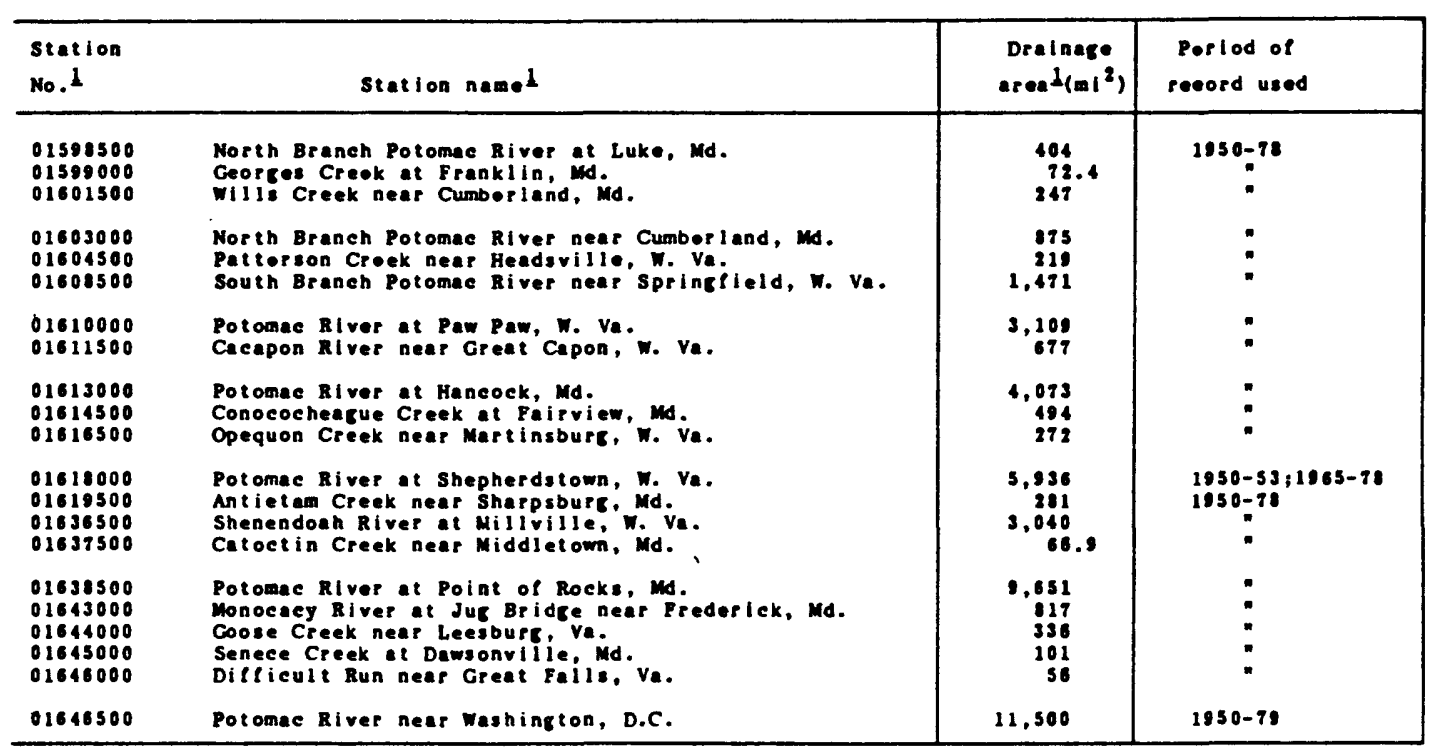

1 U.s. Ceological Survey (1981). 


\section{SUBREACH MODELS}

A flow-routing model was applied to six subreaches on the Potomac River. The endpoints of each subreach are at U.S. Geological survey stream-gaging stations. The six subreaches modeled are:

Luke, Md., to Cumber land, Md.

Cumber land, Md., to Paw Paw, W. Va.

Paw Paw, W. Va., to Hancock, Md.

Hancock, Md., to Shepherdstown, W. Va.

Shepherdstown, W. Va., to Point of Rocks, Md.

Point of Rocks, Md. to Washington, D.C.

Luke, Md., was used as the most upstream input station because it is the furthest upstream gaging station below both Bloomington and Savage Reservoirs. The subreach models permitted maximum use of available observed streamflow data, and minimized modeling errors.

The subreach models were calibrated using the following steps :

1.) Each subreach model was run using initial values (table 2) for dispersion and celerity that were computed using methods suggested by Keefer (1974).

2.) Differences (errors) between simulated and observed flows for the 1950-78 water years were evaluated. Daily volume errors, total volume errors, and root mean square (rms) errors were considered.

3.) Adjustments were made to the input parameter values and estimates of the flow from the ungaged area. Additional model runs were made to:

(a) reduce the total volume error as much as possible,

(b) distribute the daily errors evenly about zero, and to

(c) reduce the rms error as much as possible.

4.) Finally, a visual comparison was made of the simulated and observed hydrographs for the water years in which the errors were the highest, for 1966 , which was a low flow year, and for 1972, which was a high flow year. 
Table 2. -- Initial values for modeling parameters

\begin{tabular}{|c|c|c|c|c|c|c|c|}
\hline Resch & $\begin{array}{l}x^{2} 2 \\
(m i)\end{array}$ & $\begin{array}{c}Q^{1} \\
\left(s t^{3} / s\right)\end{array}$ & st 1 & $\begin{array}{c}w^{5} \\
(f t)\end{array}$ & $\begin{array}{c}K \\
\left(s t^{2} / s\right)\end{array}$ & 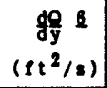 & $\begin{array}{c}C \\
(f t / s)\end{array}$ \\
\hline Luke to Cumberland & 33.7 & 990 & 0.0020 & 150 & 1,600 & 760 & 5.1 \\
\hline Cumberland to Paw Paw & 27.6 & 2,300 & .00067 & 220 & 7,800 & 1,200 & 5.5 \\
\hline Paw Paw to Hancock & 38.0 & 3,700 & .00052 & 320 & 11,000 & 1,300 & 4.7 \\
\hline Haneock to shepherdstown & 55.0 & 5,200 & .00035 & 510 & 15,000 & 2,300 & 4.5 \\
\hline Shepherdstown to Point of Rocks & 24.5 & 7,800 & .00062 & 800 & 2,000 & 3,400 & 3.9 \\
\hline Point of Rocks to washington & 42.1 & 10,000 & .00016 & 1,300 & 24,000 & 7,000 & 5.4 \\
\hline
\end{tabular}

1 U.s. Geolorical survey (1981).

2 Difference between downstream fiver mile and upstream river mile.

3 Mean of the mean flow for period of record of upstream and downstream stations.

1 Difference between cace datum for upstream and dewnstrean stations divided by the reach length.

Estimate based on stream widths shown on 1:24000 usGs topocraphic maps.

betermined from rating tables for upstrean and downstream stations.

\section{Luke to Cumberland_Calibration}

The segment of the Potomac River between Luke and Cumberland, Md., is the most upstream subreach that was modeled (fig. 4). A detailed description of the calibration of this subreach follows in order to illustrate calibration of all the subreaches.

The drainage area upstream from Luke is $404 \mathrm{mi}^{2}$. At Cumberland the drainage area is $875 \mathrm{mi}^{2}$; therefore, the intervening drainage area of the subreach is $471 \mathrm{mi}^{2}$. There are two gaged tributaries which were used in the model. Georges Creek, which flows into the North Branch Potomac just downstream from Luke, has a gaged area of $72.4 \mathrm{mi}^{2}$. Wills Creek, with a gaged area of $247 \mathrm{mi}^{2}$, flows into the North Branch Potomac just upstream from Cumberland. The ungaged area upstream from Cumberland is $152 \mathrm{mi}^{2}$.

Georges Creek flow was added to the observed flow at Luke and the summed flow was then routed to Cumberland. Flow from Wills Creek and ungaged flow were then added to the routed flow. 


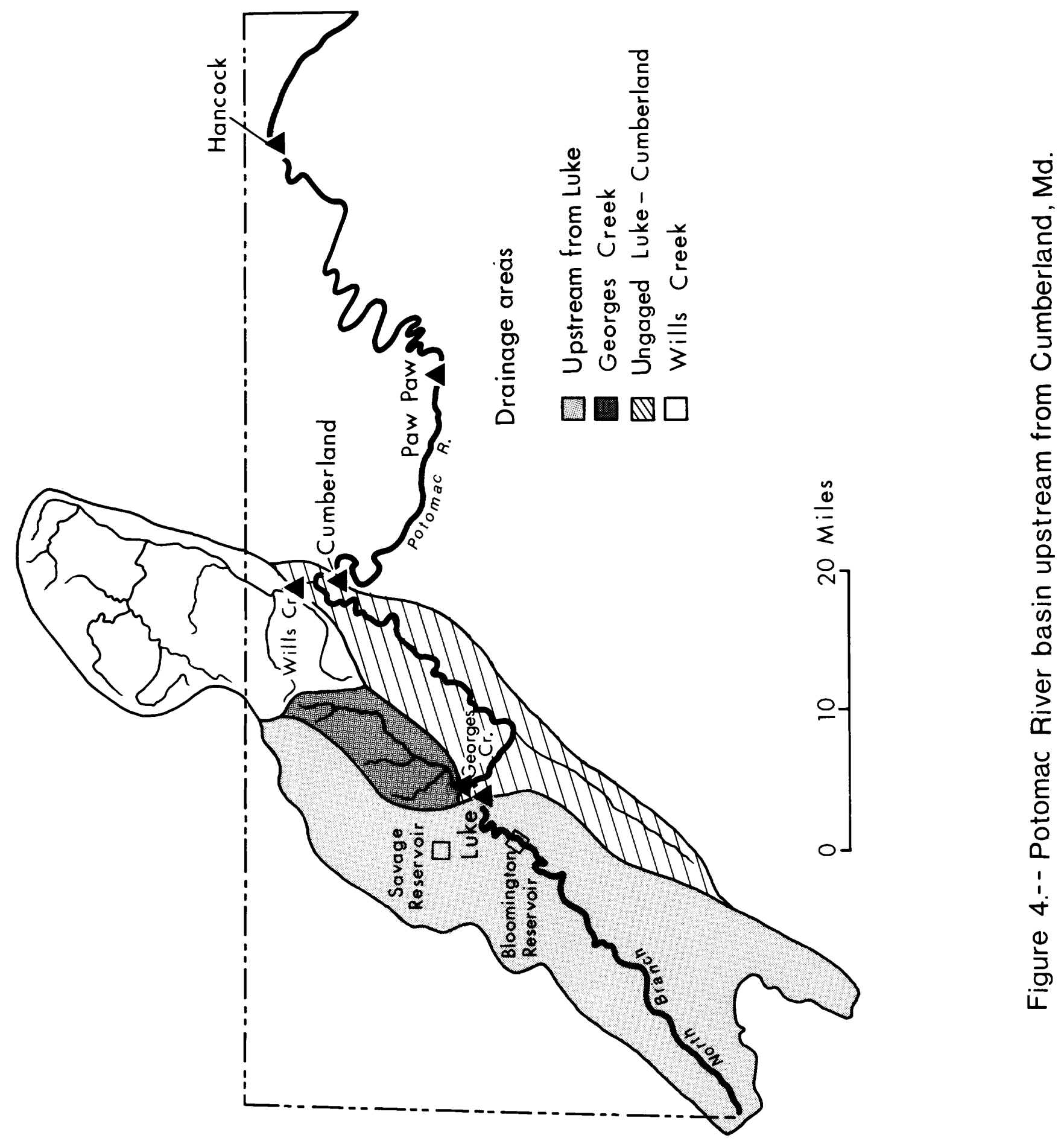


The most significant problem with subreach calibration is determining the flow contribution from the ungaged area. Ungaged intervening flow was initially estimated by multiplying the flows from Georges Creek and Wills Creek by index values based on the areal ratio of their drainage basins to the ungaged area. Using the Georges Creek drainage area, a straight drainage-area ratio yields an index value of $152 \mathrm{mi}^{2} / 72.4 \mathrm{mi}^{2}=1.10$. Using the Wills Creek drainage area, the index is $152 \mathrm{mi}^{2} / 247 \mathrm{mi}^{2}=0.615$. Neither of the above index values accurately simulated ungaged flow. By adjusting the index values for which both wills and Georges Creeks flows were multiplied, volume errors were eliminated, but the distribution of positive and negative errors was still unacceptable.

Because of the above factors, it was necessary to use a more complex method to estimate intervening ungaged flow. The result was an estimation of part of the ungaged flow by multiplying Georges Creek flows by an index of 1.2 before routing. The rest of the ungaged flow was accounted for by applying power curves to Wills Creek flows as follows:

$$
\begin{aligned}
& \text { QINTR1 }=1.348 \text { WILLS } 0.758 \text { if WILLS } \leq 290 \\
& 0.175 \text { WILLS } 1.12 \text { if WILLS }>290 \text {. }
\end{aligned}
$$

where

$$
\begin{aligned}
\text { QINTR1 } & =\text { part of ungaged flow, in } \mathrm{ft}^{3} / \mathrm{s} \text {; and } \\
\text { WILLS } & =\text { discharge at Wills Creek, in } \mathrm{ft}^{3} / \mathrm{s} \text {. }
\end{aligned}
$$

The calibrated subreach model for Luke to Cumberland is:

$$
\text { CUMBERLAND }=(\text { LUKE }+1.2 \text { GEORGES }) \text { route }+ \text { WILLS + QINTR1 }
$$

where

$$
\begin{aligned}
\text { CUMBERLAND }= & \text { discharge at the Cumberland gage; } \\
\text { LUKE }= & \text { discharge at the Luke gage; } \\
\text { GEORGES }= & \text { discharge at the Georges Creek gage; and } \\
\text { route }= & \text { routing process demonstrated in } \\
& \text { figure } 3 .
\end{aligned}
$$


The input parameters used for routing streamflow in this model are: Reach length $(\mathrm{X})=33.7 \mathrm{mi}$, dispersion $(\mathrm{K})=1,500$ $\mathrm{ft}^{2} / \mathrm{s}$, and celerity $(\mathrm{C})=3.60 \mathrm{ft} / \mathrm{s}$. The resulting routing coefficients for the unit-response function are: 0.42 for day 1 , and 0.58 for day 2. This means that for any given day, 42 percent of the observed flow at Luke will pass Cumberland on the $1^{\text {st }}$ day and 58 percent will pass Cumberland on the 2d day.

Figures 5 through 8 are hydrographs of observed and simulated flows and modeling errors for the Luke to Cumberland subreach for the water years $1952,1960,1966$, and 1972 , respectively. Observed flows are plotted as lines on the hydrographs and simulated flows are plotted as points. Below each hydrograph, daily modeling errors are plotted as percentage deviations of simulated flow from observed flow.

The rms error for 1952 is the highest of all the water years modeled and most of the daily errors (66 percent) were negative. In 1960 , most of the daily errors were positive. Flow was abnormally low in 1966 and was abnormally high in 1972 . These hydrographs show that for the model of the Luke to Cumberland subreach, simulated flows closely match observed flows. 


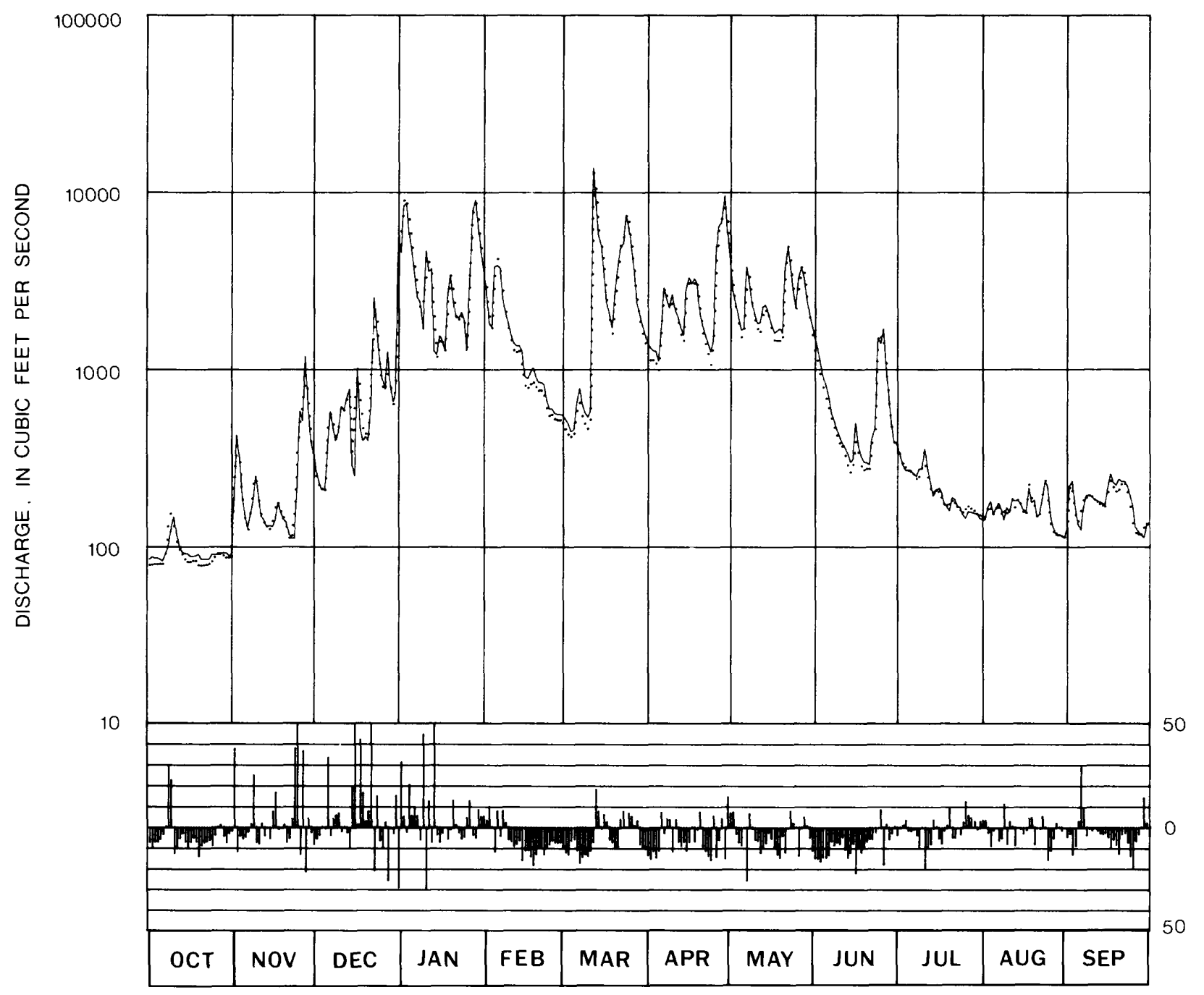

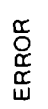

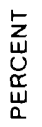

EXPLANATION

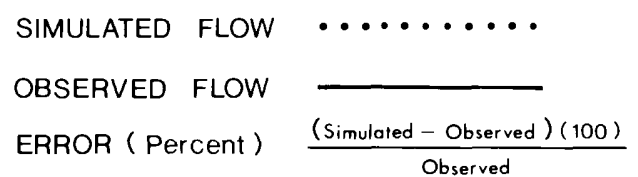

Figure 5.-- Observed and simulated flow and modeling errors at Cumberland Md., for the 1952 water year. 


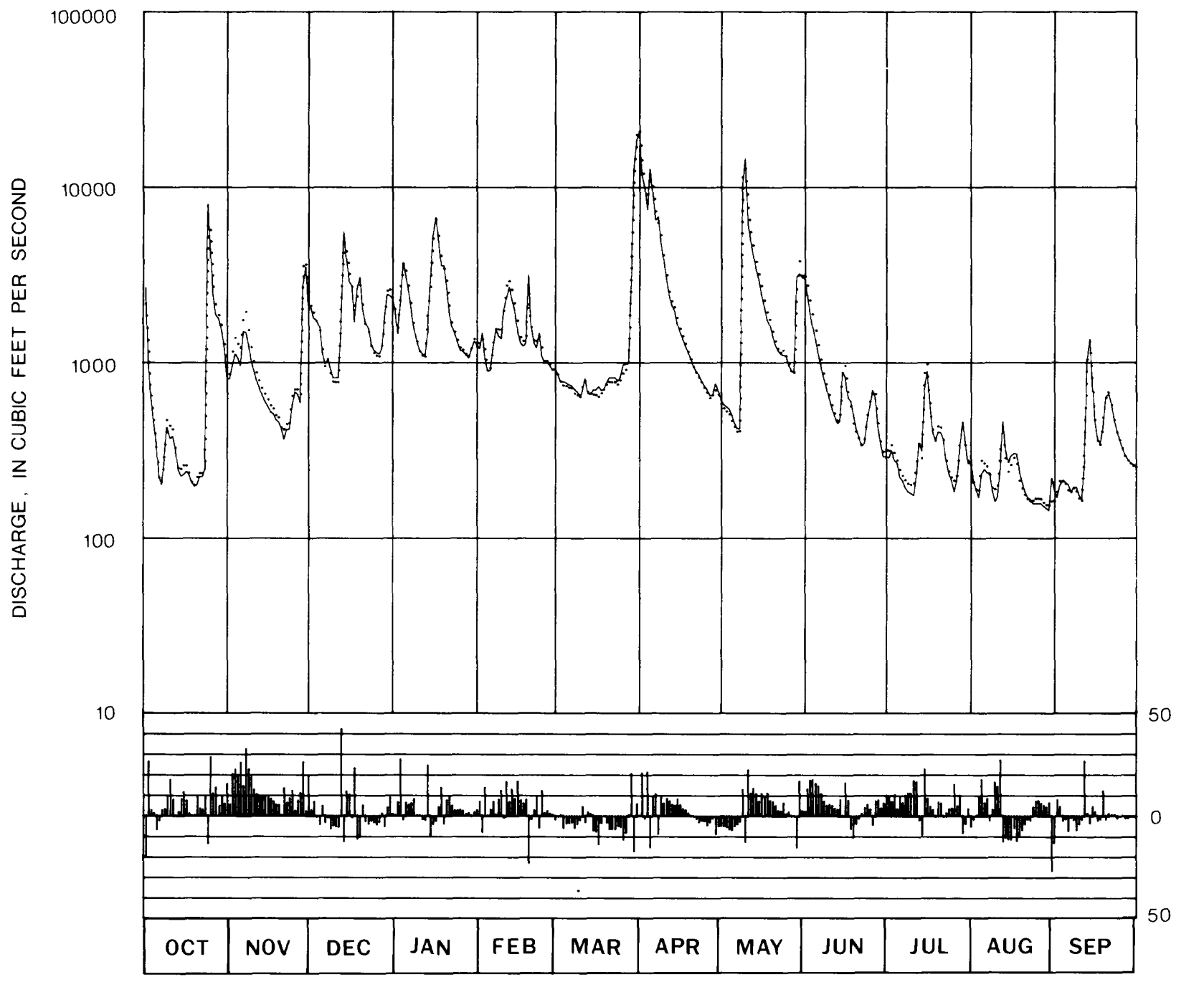

EXPLANATION

SIMULATED FLOW

OBSERVED FLOW

ERROR (Percent) $\frac{(\text { Simulated - Observed })(100)}{\text { Observed }}$

Figure 6.-- Observed and simulated flow and modeling errors at Cumberland Md., for the 1960 water year. 


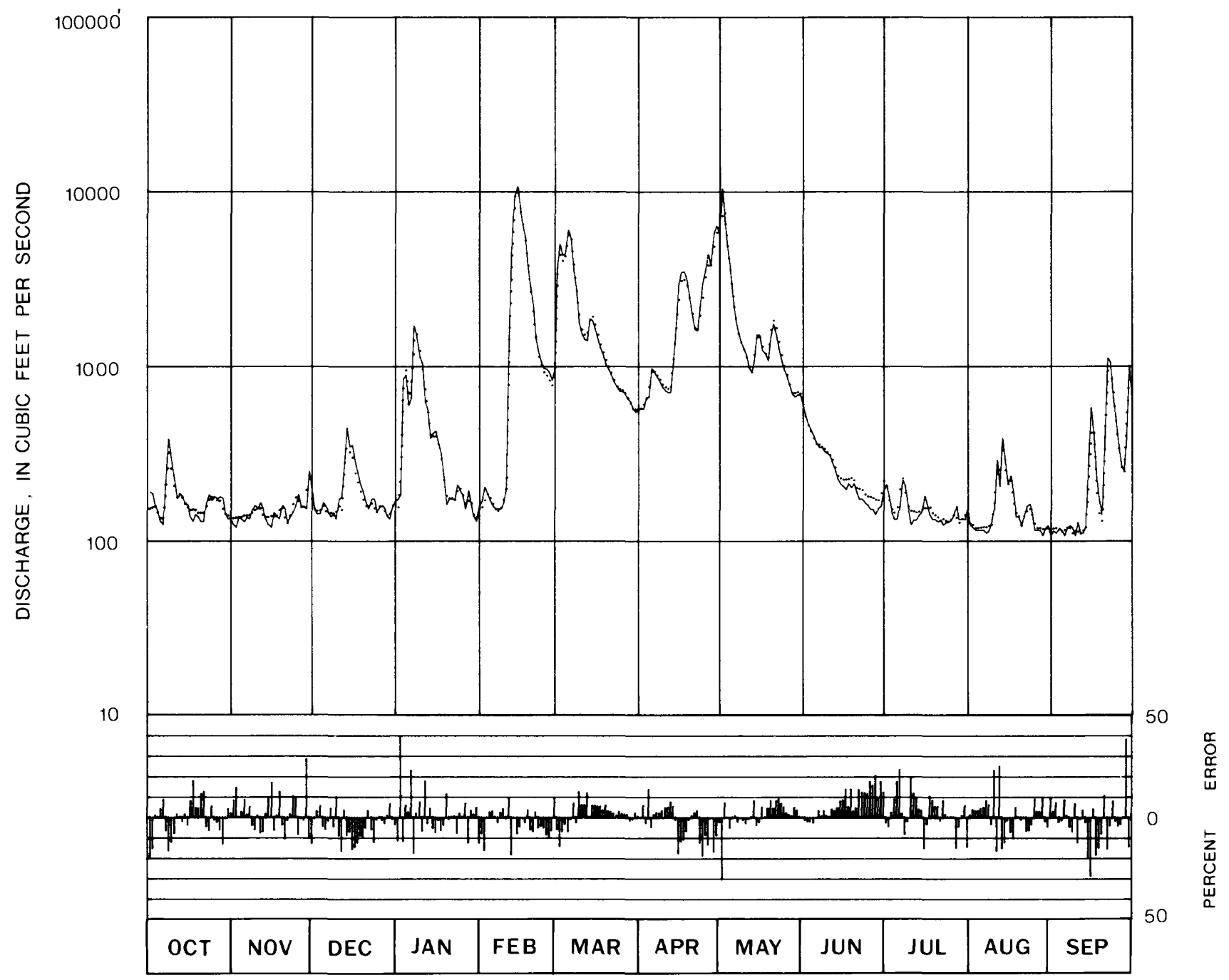

EXPLANATION

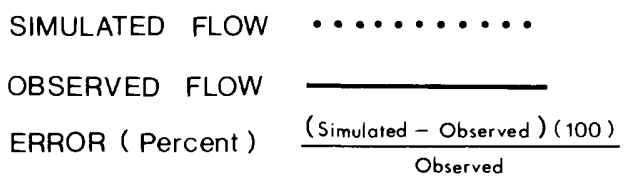

Figure 7.-- Observed and simulated flow and modeling errors at Cumberland Md., for the 1966 water year. 

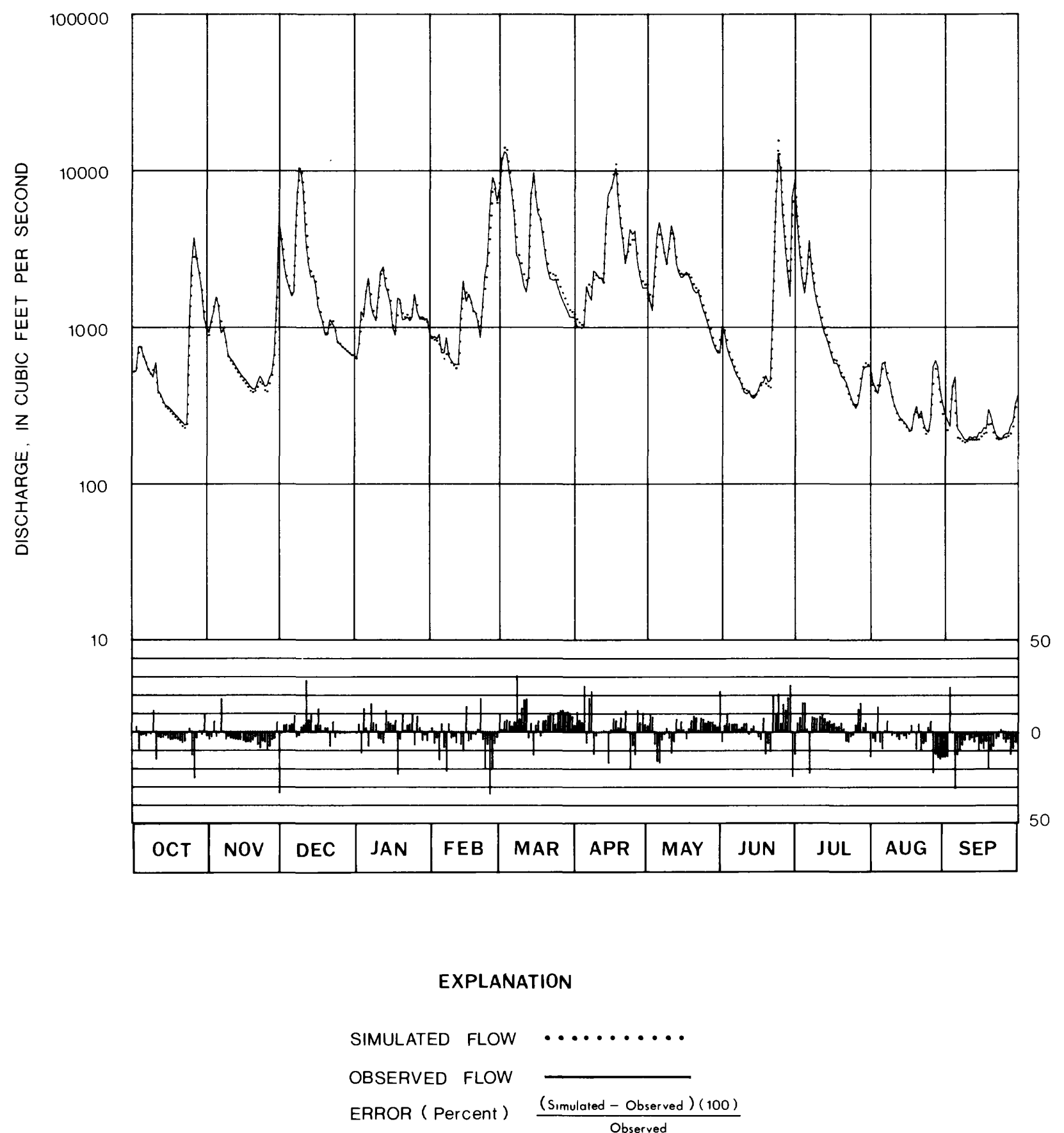

Figure 8.-- Observed and simulated flow and modeling errors at Cumberland Md., for the 1972 water year. 
Table 3 summarizes modeling errors for each of the years modeled. During the 29 years over which the model was calibrated, approximately half of the daily errors are negative and half are positive; also, the mean absolute error is 7.33 percent, and the net yearly volume error is negative for 15 years and positive for 14 years, with a total volume error of -0.70 percent. The root mean square (rms) error for the final Luke-toCumberland subreach model over the 29-year calibration period appears to be minimized and is equal to 10.74 percent.

Table 4 summarizes the daily errors or deviations in terms of number of deviations between the indicated percentages over different discharge ranges. It is important to note that overall, the distribution of positive and negative errors is approximately equal, and that 46 percent of the time, deviations are between plus and minus 5 percent, and that 76 percent of the time, deviations are between plus and minus 10 percent.

The final routing model for the subreach between Luke and Cumberland was accepted because:

1.) Hydrographs of simulated and observed flows compare well for selected water years.

2.) Total volume error is small and the number of years in which net volume error was negative compares well with the number of years in which the net volume error was positive.

3.) Daily volume errors or deviations are evenly distributed with more than three-fourths of them falling between plus and minus 10 percent.

4.) The rms errors appear to be minimized. 


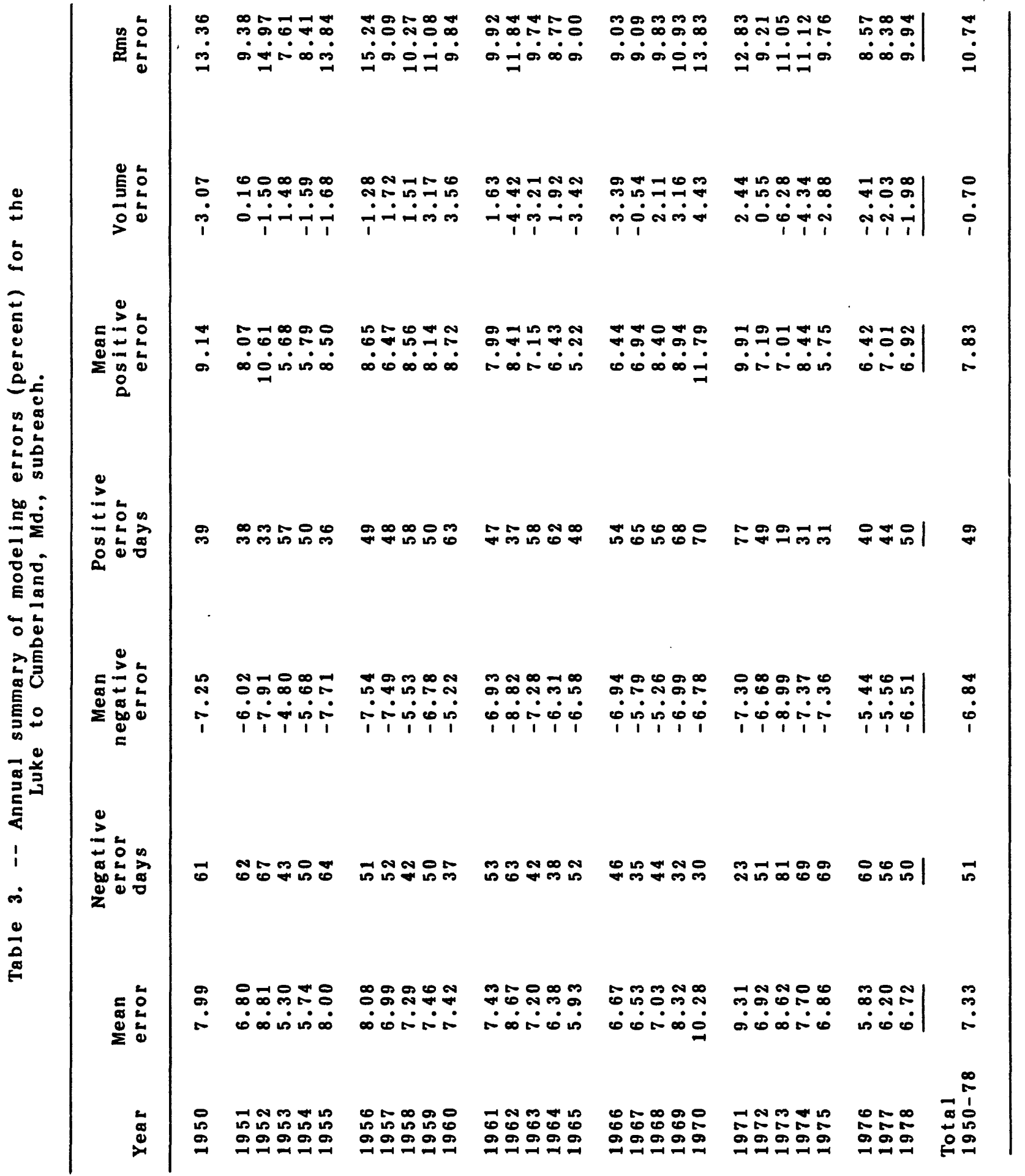


Table 4. - Distribution of daily error with discharge for Luke-to-Cumberland, Md. subreach model.

\begin{tabular}{|c|c|c|c|c|c|c|c|c|c|c|c|c|c|c|c|}
\hline \multirow{2}{*}{$\begin{array}{c}\text { Discharge } \\
\left(\mathrm{ft}^{3} / \mathrm{s}\right)\end{array}$} & \multicolumn{14}{|c|}{ Number of days that daily error was between specified percentages } & \\
\hline & $<$ & -30 & -25 & -20 & -15 & -10 & -5 & 0 & 5 & 10 & 15 & 20 & 25 & 30 & \\
\hline $0-$ & 0 & 0 & 0 & 0 & 3 & 19 & 7 & 3 & 0 & 1 & 1 & 0 & 0 & 0 & \\
\hline 83 & 0 & 0 & 0 & 1 & 2 & 6 & 16 & 59 & 34 & 7 & 3 & 1 & 7 & 1 & \\
\hline 98 & 0 & 0 & 0 & 3 & 7 & 26 & 89 & 125 & 71 & 17 & 7 & 1 & 2 & 1 & \\
\hline 120 & 0 & 0 & 1 & 1 & 20 & 45 & 104 & 142 & 63 & 17 & 17 & 5 & 4 & 4 & \\
\hline 140 & 0 & 0 & 0 & 10 & 47 & 101 & 125 & 151 & 105 & 42 & 23 & 12 & 2 & 11 & \\
\hline 160 & 1 & 2 & 4 & 20 & 53 & 103 & 176 & 167 & 76 & 40 & 15 & 8 & 2 & 7 & \\
\hline 190 & 0 & 2 & 4 & 16 & 41 & 102 & 150 & 106 & 64 & 22 & 15 & 8 & 2 & 8 & \\
\hline 230 & 0 & 0 & 3 & 13 & 45 & 99 & 132 & 114 & 52 & 21 & 10 & 8 & 4 & 7 & \\
\hline 270 & 0 & 1 & 1 & 12 & 29 & 89 & 127 & 116 & 46 & 25 & 11 & 11 & 1 & 8 & \\
\hline & 1 & 0 & 1 & 9 & 25 & 95 & 139 & 116 & 70 & 30 & 12 & 5 & 6 & 6 & \\
\hline & 2 & 2 & 4 & 9 & 27 & 81 & 149 & 125 & 78 & 36 & 14 & 6 & 2 & 8 & \\
\hline 450 & 1 & 2 & 4 & 13 & 23 & 91 & 134 & 126 & 70 & 50 & 13 & 3 & 3 & 9 & \\
\hline 540 & 0 & 0 & 9 & 7 & 26 & 89 & 158 & 118 & 67 & 37 & 16 & 11 & 4 & 1 & \\
\hline 640 & 0 & 0 & 5 & 16 & 49 & 91 & 116 & 114 & 41 & 32 & 15 & 6 & 2 & 4 & \\
\hline 750 & 3 & 1 & 11 & 21 & 60 & 112 & 135 & 117 & 75 & 42 & 16 & 15 & 9 & 6 & \\
\hline 890 & 3 & 3 & 9 & 15 & 40 & 92 & 110 & 97 & 73 & 31 & 17 & 8 & 4 & 3 & \\
\hline 1,100 & 0 & 4 & 5 & 12 & 30 & 52 & 86 & 73 & 61 & 36 & 15 & 5 & 4 & 3 & \\
\hline 1,300 & 0 & 2 & 4 & 10 & 33 & 79 & 120 & 105 & 56 & 33 & 17 & 5 & 3 & 10 & \\
\hline 1,500 & 2 & 2 & 4 & 8 & 27 & 63 & 21 & 85 & 55 & 25 & 11 & 4 & 4 & 6 & \\
\hline 1,800 & 3 & 4 & 7 & 11 & 24 & 57 & 85 & 87 & 42 & 30 & 14 & 8 & 4 & 1 & \\
\hline & 3 & 1 & 5 & 6 & 21 & 32 & 66 & 56 & 43 & 11 & 9 & 6 & 2 & 3 & \\
\hline 100 & 3 & 2 & 4 & 12 & 30 & 40 & 57 & 59 & 57 & 25 & 8 & 4 & 0 & 4 & \\
\hline & 2 & 4 & 8 & 8 & 18 & 25 & 34 & 47 & 47 & 19 & 2 & 2 & 2 & 1 & \\
\hline & 3 & 3 & 5 & 6 & 9 & 27 & 32 & 45 & 30 & 16 & 5 & 1 & 4 & 3 & \\
\hline & 3 & 3 & 0 & 6 & 13 & 12 & 24 & 19 & 24 & 13 & 2 & 4 & 1 & 2 & \\
\hline nn & 1 & 2 & 4 & 7 & 5 & 21 & 18 & 18 & 13 & 6 & 3 & 3 & 0 & 3 & \\
\hline 0 & 0 & 3 & 2 & 4 & 10 & 11 & 18 & 26 & 5 & 5 & 1 & 2 & 1 & 2 & \\
\hline & 3 & 1 & 3 & 2 & 7 & 5 & 12 & 11 & 11 & 4 & 2 & 0 & 0 & 0 & \\
\hline & 1 & 0 & 0 & 2 & 3 & 3 & 4 & 6 & 4 & 1 & 0 & 1 & 0 & 0 & \\
\hline & 1 & 0 & 2 & 6 & & 5 & 6 & 3 & 3 & 2 & 0 & 2 & 0 & 0 & \\
\hline & 0 & 2 & 1 & 1 & 3 & 4 & 1 & 3 & 2 & 0 & 1 & 0 & 0 & 0 & \\
\hline & 1 & 1 & 0 & 0 & 1 & 2 & 0 & 1 & 1 & 0 & 0 & 0 & 0 & 0 & \\
\hline 10 0 & 0 & 1 & 1 & 0 & 0 & 0 & 0 & 1 & 0 & 0 & 0 & 0 & 0 & 0 & \\
\hline 22,000 & 0 & 1 & 0 & 0 & 1 & 0 & 0 & 0 & 0 & 0 & 0 & 0 & 0 & 0 & \\
\hline & & & & & & & & & & & & & & & Totel \\
\hline SUM & 38 & 49 & 106 & 267 & 739 & 1674 & 2511 & 2447 & 1439 & 676 & 295 & 155 & 74 & 122 & 10592 \\
\hline $\begin{array}{l}\text { Percent } \\
\text { of total }\end{array}$ & .4 & .5 & 1.0 & 2.5 & 7.0 & 15.8 & 23.7 & 23,1 & 13.6 & 6.4 & 2.8 & 1.5 & .7 & 1.2 & 100.2 \\
\hline
\end{tabular}




\section{Summary_of_Subreach_Results}

The other five subreaches were calibrated in the same manner as the Luke to Cumberland subreach. The results of the subreach calibration are shown in table 5 , which 1 ists the calibrated subreach models, input parameters, and the unit-response coefficients used for routing flows in each subreach.

The Hancock to Shepherdstown subreach was divided into two parts. In the first part, a reach length of $55 \mathrm{mi}$ is used to route flows from the upper portion of the subreach to Shepherdstown. In the second part, a reach length of $25 \mathrm{mi}$ is used to routeflows from the central and lower portions of the subreach.

On the Shepherdstown to Point of Rocks subreach, flow from Catoctin Creek is lagged 6 hours. This is accomplished by the following:

where

$$
\mathrm{Q} \operatorname{ag}_{\mathrm{n}}=0.75 \mathrm{Q}_{\mathrm{n}-1}+0.25 \mathrm{Q}_{\mathrm{n}} \text {. }
$$

$$
\begin{aligned}
\text { Q1ag } & =\text { lagged flow; } \\
\mathbf{n} & =\text { day in which flow occurrs; and } \\
\mathbf{Q} & =\text { observed flow. }
\end{aligned}
$$

This lagging feature is a method of accounting for the traveltime of flows from the mouth of Catoctin Creek through the Potomac River to Point of Rocks. 


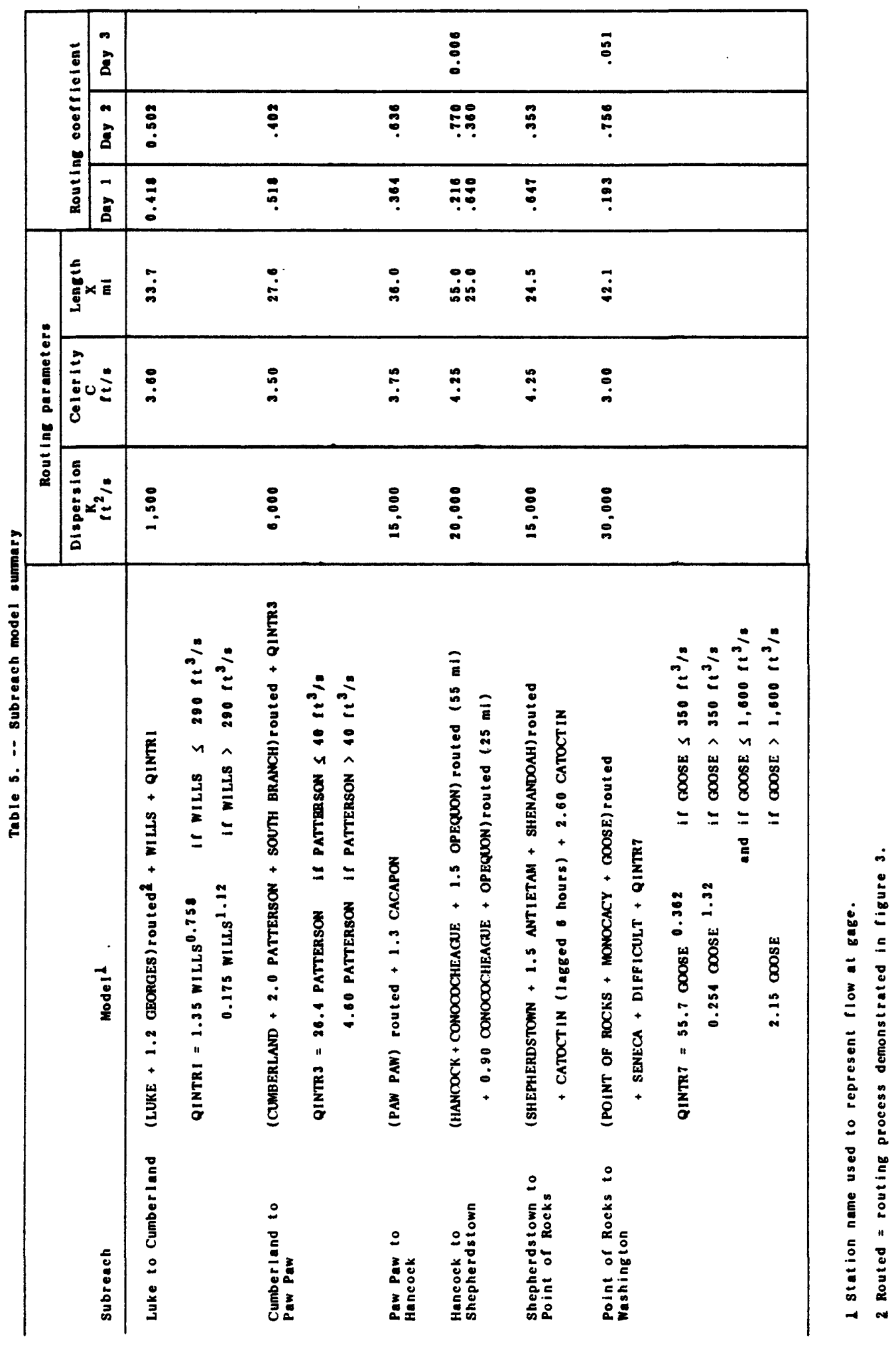


Table 6 summarizes the modeling errors over the indicated calibration period for each subreach, and table 7 summarizes the daily errors. Four of the subreaches were calibrated for the 1950-78 water years. The Hancock, Md., to Shepherdstown, W. Va., and Shepherdstown to Point of Rocks, Md., subreaches could not be calibrated for this period because shepherdstown has an incomplete record. These two subreaches were calibrated for the periods 1950-53 and 1965-78. As table 7 shows, mean error for each of the six subreaches is less than 10 percent. In each subreach, there are approximately the same percentage of negative-error and positive-error days, and the mean positive and mean negative errors have an absolute value of less than 10 percent. The rms errors all appear to be minimized.

Although all of the volume errors in table 6 are relatively low, they are all negative except for the 1950-53 water years on the Shepherdstown to Point of Rocks subreach. Volume errors are negative because the model tends to underestimate peak flows. Hence, there are many days of high flow showing a negative volume error. Because a small negative error for a day with high flow can represent a large quantity of water, a net negative volume error can occur with a few high flow periods.

\begin{tabular}{|c|c|c|c|c|c|c|c|c|}
\hline Subreach & $\begin{array}{c}\text { Calibration } \\
\text { pariod } \\
\text { (water years) }\end{array}$ & $\begin{array}{l}\text { Mean } \\
\text { error }\end{array}$ & $\begin{array}{l}\text { Nagative } \\
\text { errop } \\
\text { days }\end{array}$ & $\begin{array}{l}\text { Mean } \\
\text { negative } \\
\text { error }\end{array}$ & $\begin{array}{l}\text { Positive } \\
\text { erfor } \\
\text { days }\end{array}$ & $\begin{array}{l}\text { Mean } \\
\text { positive } \\
\text { error }\end{array}$ & $\begin{array}{l}\text { Vol uma } \\
\text { error }\end{array}$ & $\begin{array}{l}\text { Ras } \\
\text { error }\end{array}$ \\
\hline Luke to Cumber land & $1950-78$ & 7.33 & 51 & -6.84 & 49 & 7.83 & -0.70 & 10.74 \\
\hline Cumbarland to Paw Paw & $1950-78$ & 8.11 & 48 & -7.48 & 52 & 8.71 & -1.88 & 12.14 \\
\hline Paw Puw to Hancock & $1950-78$ & 6.16 & 49 & -5.82 & 51 & 6.48 & -1.48 & 12.38 \\
\hline Hancock to Sheperdstown & $\begin{array}{l}1950=53 \\
198.5=78\end{array}$ & $\begin{array}{l}8.55 \\
8.22\end{array}$ & $\begin{array}{l}47 \\
47\end{array}$ & $\begin{array}{l}-7.26 \\
-7.82\end{array}$ & $\begin{array}{l}53 \\
53\end{array}$ & $\begin{array}{l}9.69 \\
8.78\end{array}$ & $\begin{array}{l}-3.40 \\
-3.81\end{array}$ & $\begin{array}{l}15.40 \\
13.10\end{array}$ \\
\hline $\begin{array}{l}\text { Shepherdstown to } \\
\text { Point of Rocks }\end{array}$ & $\begin{array}{l}1950=53 \\
1965-78\end{array}$ & $\begin{array}{l}4.38 \\
6.33\end{array}$ & $\begin{array}{l}49 \\
46\end{array}$ & $\begin{array}{l}-3.52 \\
-5.02\end{array}$ & $\begin{array}{l}51 \\
54\end{array}$ & $\begin{array}{l}5.17 \\
7.47\end{array}$ & $\begin{array}{r}0.10 \\
-0.17\end{array}$ & $\begin{array}{l}6.70 \\
9.42\end{array}$ \\
\hline $\begin{array}{l}\text { Point of Rocks to } \\
\text { Washington }\end{array}$ & $1950-78$ & 6.43 & 50 & -6.20 & so. & 6.86 & -0.20 & 10.00 \\
\hline
\end{tabular}


Table 7. -- Sumary of daily errors for subreach models

\begin{tabular}{|c|c|c|c|c|c|c|c|c|c|c|c|c|c|c|c|c|c|c|}
\hline \multirow[b]{2}{*}{ Subreech } & \multirow{2}{*}{\multicolumn{2}{|c|}{$\begin{array}{l}\text { Calibration } \\
\text { period }\end{array}$}} & \multicolumn{16}{|c|}{$\begin{array}{l}\text { Percentage of days that dally error } \\
\text { was between indicated percent error }\end{array}$} \\
\hline & & & $<-30$ & -25 & -20 & -15 & -10 & & s & 0 & 5 & 10 & & & 20 & 25 & 30 & $>$ \\
\hline Luke to Cumber land & 1950 & -78 & 0.4 & 0.5 & 1.0 & 2.5 & 7.0 & 15.8 & 23.7 & 23.1 & & & 6.4 & & 8 & 1.5 & 0.7 & 1.2 \\
\hline Cumberland to Paw Puw & & $n$ & .9 & .8 & 1.2 & 2.8 & 5.8 & 14.2 & 22.5 & 22.5 & & & 7.2 & & 6 & 1.8 & .9 & 1.6 \\
\hline Paw Paw to Hancock & & $n$ & .7 & .3 & .8 & 2.0 & 4.2 & 11.5 & 30.2 & 29.8 & & & 4.2 & & .3 & .8 & .4 & 1.1 \\
\hline Hancock to Shepherdstown & $\begin{array}{l}1950 \\
1965\end{array}$ & $\begin{array}{l}-53 \\
-78\end{array}$ & $\begin{array}{l}1.0 \\
1.7\end{array}$ & $\begin{array}{r}.9 \\
1.2\end{array}$ & $\begin{array}{l}1.5 \\
1.8\end{array}$ & $\begin{array}{l}3.6 \\
2.9\end{array}$ & $\begin{array}{l}4.7 \\
4.5\end{array}$ & $\begin{array}{l}10.4 \\
11.3\end{array}$ & $\begin{array}{l}25.1 \\
26.1\end{array}$ & $\begin{array}{l}28.0 \\
27.1\end{array}$ & & & $\begin{array}{l}5.1 \\
6.8\end{array}$ & & $\begin{array}{l}.6 \\
.5\end{array}$ & $\begin{array}{l}1.6 \\
1.8\end{array}$ & $\begin{array}{r}1.2 \\
.9\end{array}$ & $\begin{array}{l}3.6 \\
2.8\end{array}$ \\
\hline $\begin{array}{l}\text { Shepherdstown to } \\
\text { Point of Rocks }\end{array}$ & $\begin{array}{l}1950 \\
1965\end{array}$ & $\begin{array}{l}-53 \\
-78\end{array}$ & $\begin{array}{l}0 \\
0\end{array}$ & $\begin{array}{l}0 \\
0\end{array}$ & .12 & .5 & $\begin{array}{l}2.1 \\
3.5\end{array}$ & $\begin{array}{r}7.9 \\
15.8\end{array}$ & $\begin{array}{l}38.3 \\
27.7\end{array}$ & $\begin{array}{l}32.8 \\
25.3\end{array}$ & & & $\begin{array}{l}3.4 \\
8.1\end{array}$ & & .6 & $\cdot .5$ & .5 & 1.4 \\
\hline $\begin{array}{l}\text { Point of Rocks } \\
\text { to Washington }\end{array}$ & 1950 & -79 & .5 & .6 & 1.0 & 1.6 & 5.1 & 14.4 & 27.0 & 27.3 & & & 4.7 & & .1 & .9 & .5 & .9 \\
\hline
\end{tabular}

\section{LIKKKED MODEL}

To implement the flow-routing model for the Potomac River between Luke, Md., and Washington, D.C., it was necessary to link the subreach models together. The linked model uses only the observed flow at Luke, observed tributary flow, and estimated ungaged intervening flow to simulate the flow at the downstream end of each subreach. The results of the model are the routing coefficients used to transport water downstream from Luke. The model was calibrated for the 1950-78 water years.

The standard method used to link subreach models is to use the simulated daily flow from an upper subreach model as input to the next lower subreach model. One of the problems with this method is that it can cause significant timing errors. These errors could be as much as 12 hours per reach.

To link the subreaches in this study, hourly routing coefficients were generated by each of the subreach models. These hourly coefficients were then combined and re-expressed as daily routing coefficients for the linked model. Table 9 gives the daily coefficients resulting from the combined hourly coefficients. 
Figures 9 through 12 are hydrographs of observed and simulated flows at washington, D.C., for the 1955, 1966, 1972, and 1978 water years, respectively. For 1955 , the rms errors are the highest of the water years modeled and most of the daily errors ( 60 percent) are positive. The hydrograph for 1966 is shown because that was the year of lowest flow. In 1972 , flows were high. For 1978 , most of the daily errors (57 percent) were negative. The $f$ it of the simulated flows to the observed flows is generally good. Most of the excessively high errors occurred at or near peaks in the flow and were the result of 1-day timing errors. Because daily flows are used in the model, there is a loss of resolution, which results in these timing errors.

Table 8 summarizes the modeling errors for the linked model from Luke, Md., to Washington, D.C. As would be expected, the errors and deviations are somewhat higher in the linked model than in the subreach model. However, the difference does not appear to be significant.

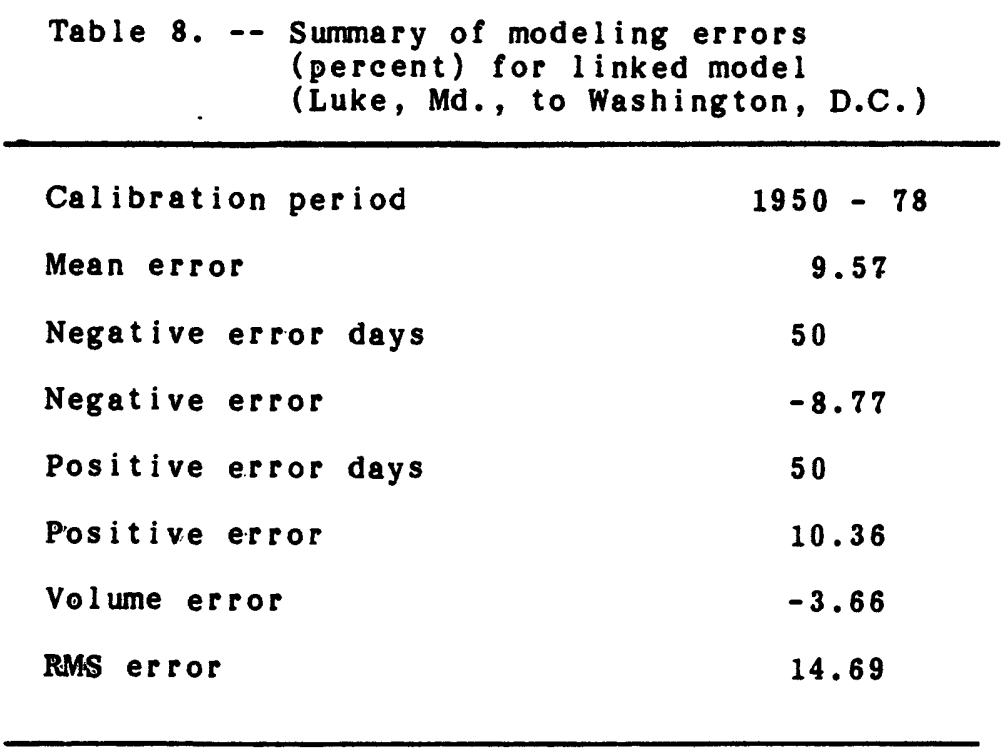




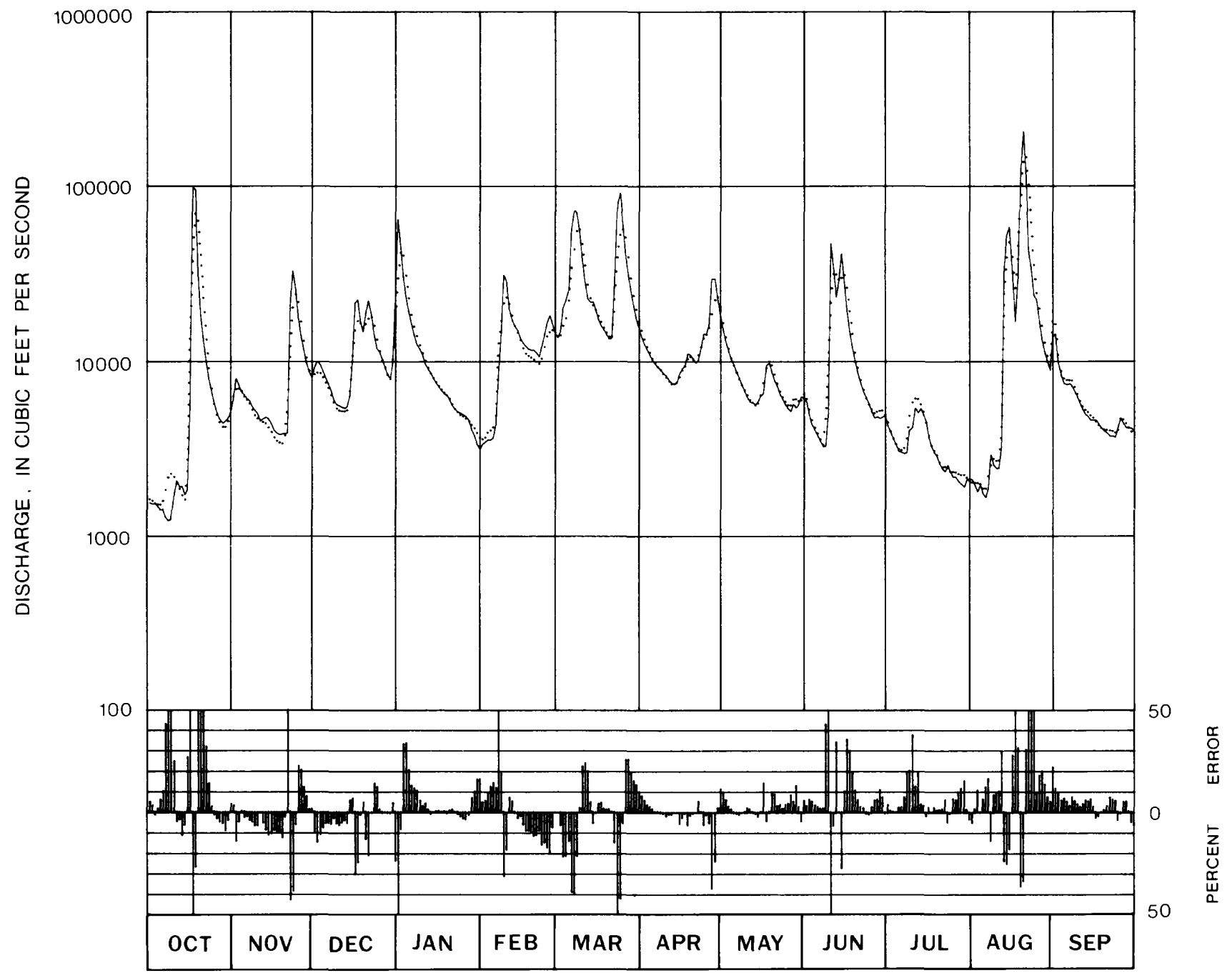

EXPLANATION

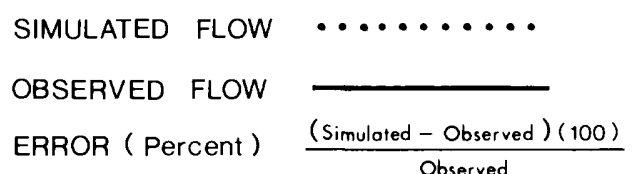

Figure 9.-- Observed and simulated flow and modeling errors at Washington, D.C., using the linked model for the 1955 water year. 


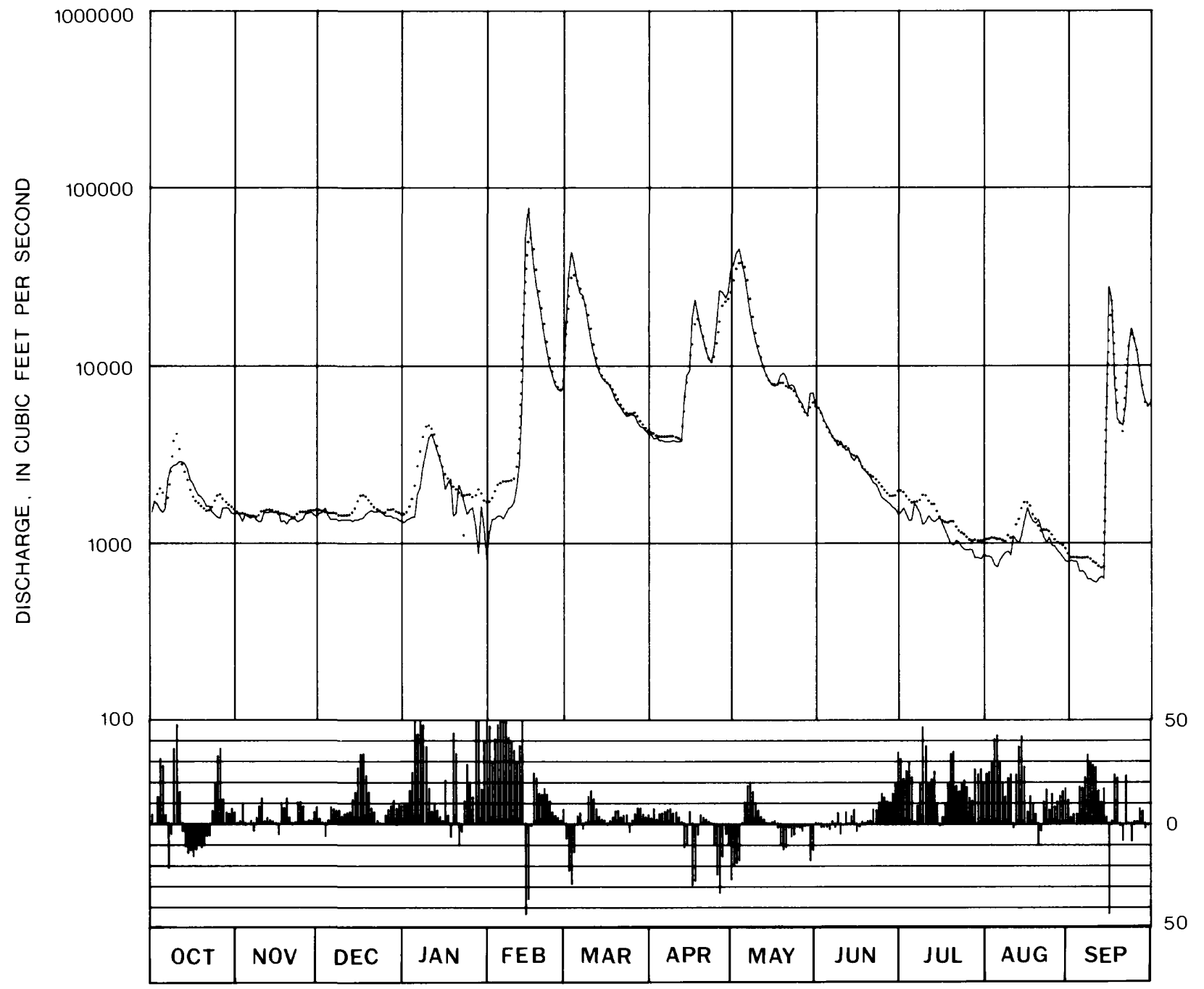

EXPLANATION

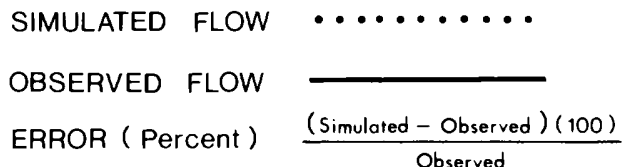

Figure 10.-- Observed and simulated flow and modeling errors at Washington, D.C., using the linked model for the 1966 water year. 


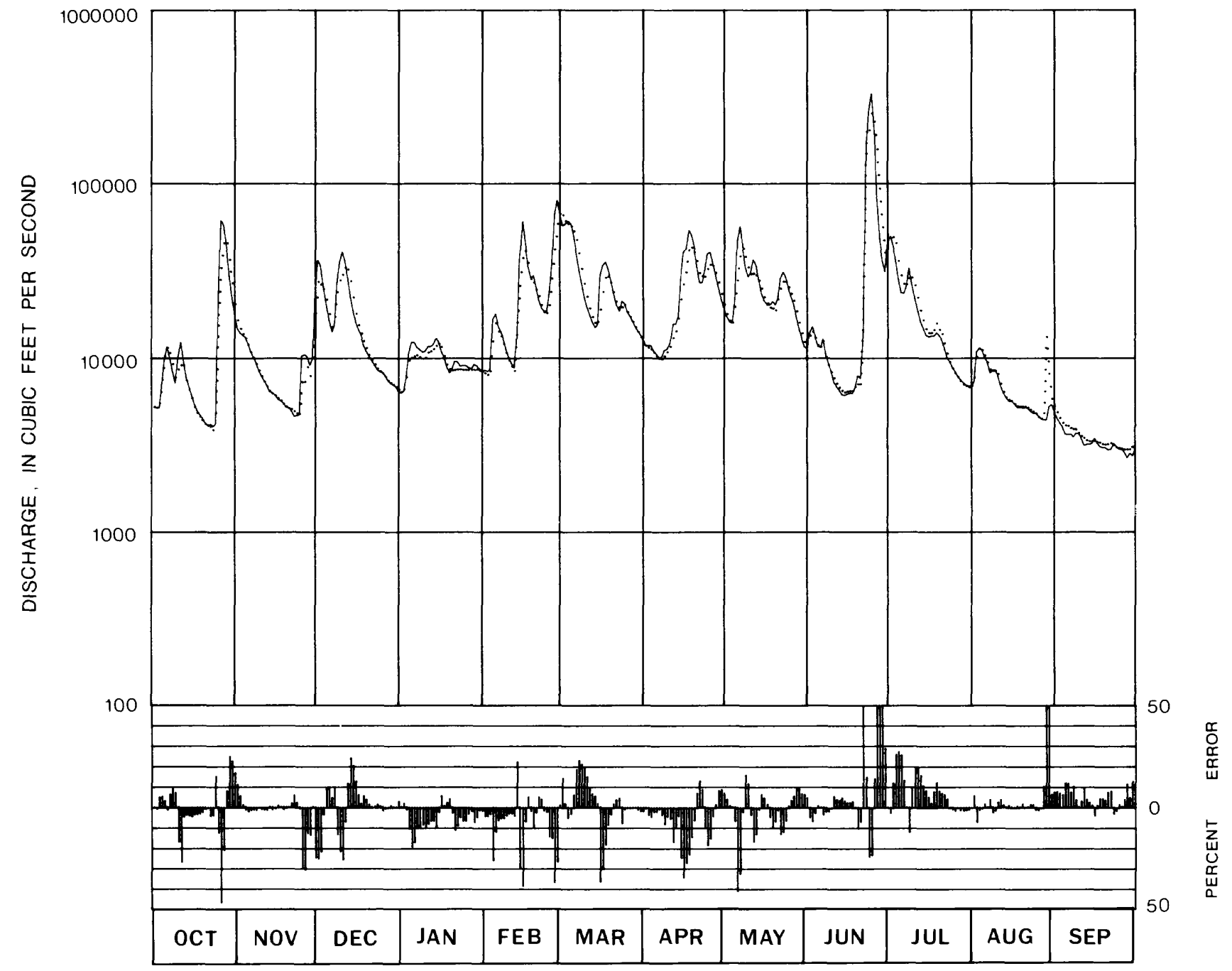

EXPLANATION

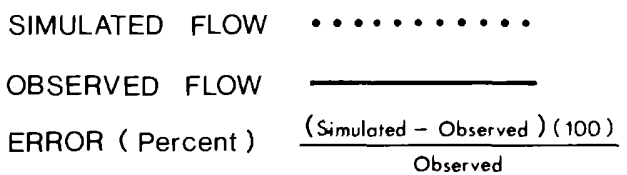

Figure 11.-- Observed and simulated flow and modeling errors at Washington, D.C., using the linked model for the 1972 water year. 


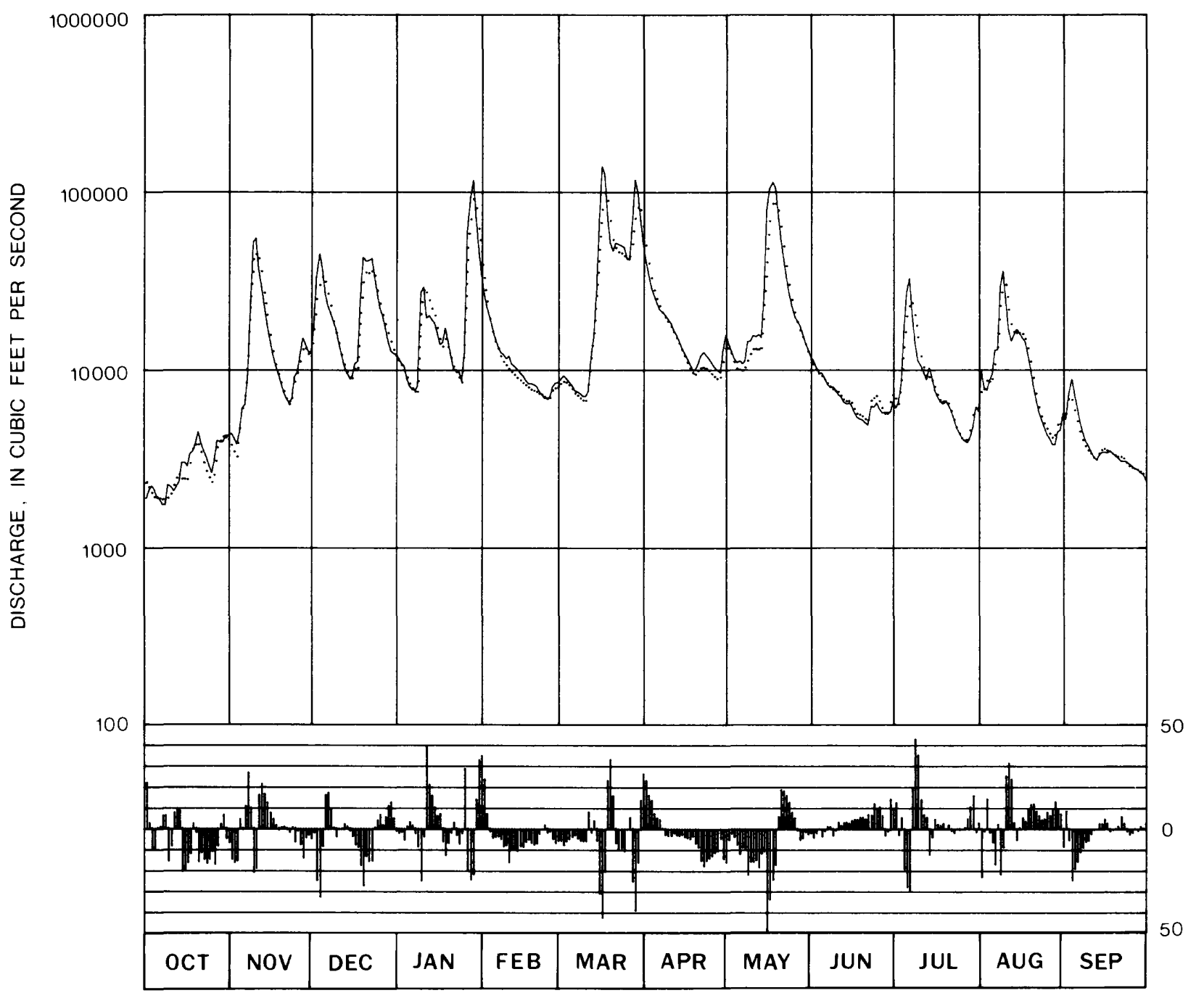

\section{EXPLANATION}

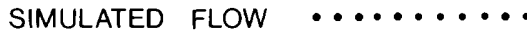

OBSERVED FLOW

ERROR (Percent) (Simulated - Observed) (100)

Figure 12.-- Observed and simulated flow and modeling errors at Washington, D.C., using the linked model for the 1978 water year. 


\section{UNIT RESPONSE TO RESERVOIR RELEASES}

Unit response to reservoir releases developed by the 1 inked model are expressed in table 9 as daily routing coefficients. The same unit response is expressed in table 10 as 12-hour routing coefficients, and in table 11 as weekly routing coefficients.

Daily coefficients can be used to estimate the response at each of the listed stations for releases made on a daily schedule. For example, if $100 \mathrm{ft}^{3} \mathrm{~s}$ is released for one day, 35 $\mathrm{ft}^{3} / \mathrm{s}$ will pass Washington, D.C., on the $4 \mathrm{th}$ day, $61 \mathrm{ft}^{3} / \mathrm{s}$ on the $5 \mathrm{th}$ day and $4 \mathrm{ft}^{3} / \mathrm{s}$ on the $6 \mathrm{th}$ day. The 12 -hour and weekly routing coefficients can be used to determine downstream response in the same manner as the daily routing coefficients. The choice of which set of coefficients are used depends on the application and degree of precision required.

Figure 13 illustrates the results of routing a 3 -day unit reservoir release from Luke to Washington using a 12-hour unitresponse function. Releases for each 12-hour period are shaded to indicate the distribution of flows at Washington. The total 12-hour response is the summation of component responses for that 12-hour period. The daily response, again, is the mean flow for the two 12-hour periods for each day.

Using the model, figure 14 illustrates movement of a 7-day unit input at Luke, spreading out as it flows to washington. Approximate hourly response is indicated by the curvature at the beginning and end of the response period. It should be noted that essentially all the water has passed Washington by the end of day 11 ( 4 th day of $2 d$ week). 
Table 9. - Daily routing coefficients for linked models

\begin{tabular}{|c|c|c|c|c|c|c|c|}
\hline \multirow{2}{*}{$\begin{array}{l}\text { Reach } \\
\text { Luke to: }\end{array}$} & \multicolumn{7}{|c|}{ Routing coefficients for day } \\
\hline & 1 & 2 & 3 & 4 & 5 & 6 & 7 \\
\hline Cumberland & 0.42 & 0.58 & -- & -- & -- & -- & -- \\
\hline Puw Paw. & .02 & .91 & 0.07 & -- & -- & -- & - \\
\hline Hancock & -- & .31 & .69 & -- & -- & -- & -- \\
\hline Shepherdstown & -- & -- & .52 & 0.48 & -- & -- & -- \\
\hline Points of Rocks & -- & -- & .20 & .77 & 0.03 & -- & - \\
\hline Washington & -- & -- & -- & .35 & .61 & 0.04 & -- \\
\hline
\end{tabular}

Toble 10. -- Twelve-hour routing coefficients for linked models

\begin{tabular}{|c|c|c|c|c|c|c|c|c|c|c|c|}
\hline \multirow{2}{*}{$\begin{array}{l}\text { Reach } \\
\text { Luke to: }\end{array}$} & \multicolumn{5}{|c|}{ Routing coefficients } & \multicolumn{6}{|c|}{ for indicated 12-hour period } \\
\hline & $0-12$ & $12-24$ & $24-36$ & $36-48$ & $48-60$ & $60-72$ & $72-84$ & $84-96$ & $96-108$ & $108-120$ & $120-132$ \\
\hline Cumber 1 and & -- & 0.86 & 0.14 & -- & -- & -- & -- & -- & -- & -- & -- \\
\hline Paw Paw & -- & .03 & .83 & 0.14 & -- & -- & -- & -- & -- & -- & -- \\
\hline Hencock & -- & .01 & .60 & 0.38 & 0.01 & -- & -- & -- & -- & -- & -- \\
\hline Shepherdstown & -- & -- & -- & .19 & .66 & 0.15 & -- & - & -- & -- & -- \\
\hline Point of Rocks & -- & -- & -- & -- & .01 & .38 & 0.54 & 0.07 & $\cdots$ & -- & -- \\
\hline Weshington & -- & -- & -- & -- & -- & -- & .11 & $.47^{\circ}$ & 0.34 & 0.07 & 0.01 \\
\hline
\end{tabular}

\begin{tabular}{l|r|r|} 
Table 11. - Weekly routing coefficients for linked model \\
\hline Reach & \multicolumn{2}{|c|}{ Routing coefficients } \\
Luke to: & 1 & 2 \\
\cline { 2 - 3 } & 0.92 & 0.08 \\
Cumberland & .85 & .15 \\
Paw Paw & .76 & .24 \\
Hancock & .65 & .35 \\
Shepherdstown & .60 & .40 \\
Point of Rocks & .47 & .53 \\
\hline
\end{tabular}




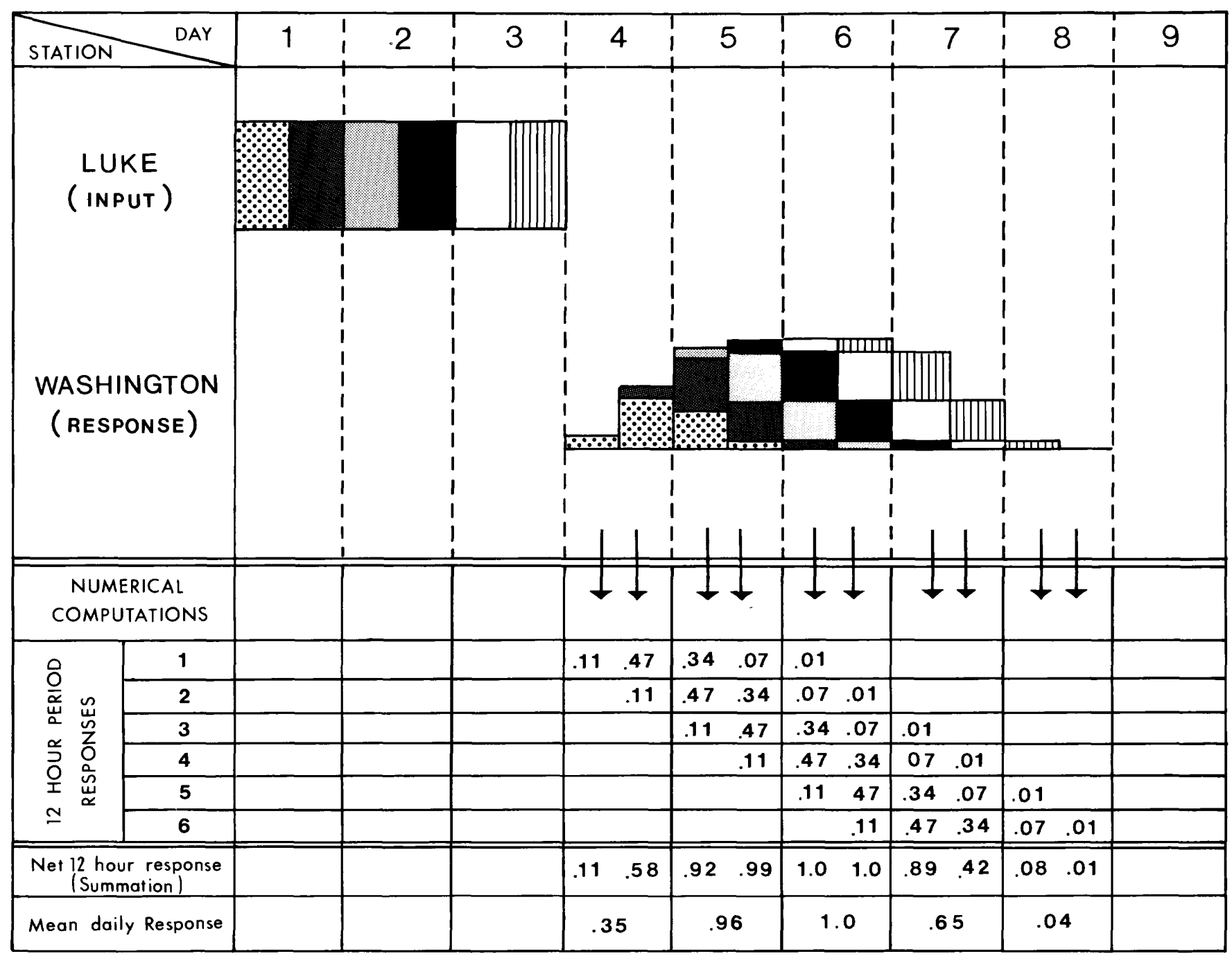

EXPLANATION

FLOW AT LUKE FOR HOURS

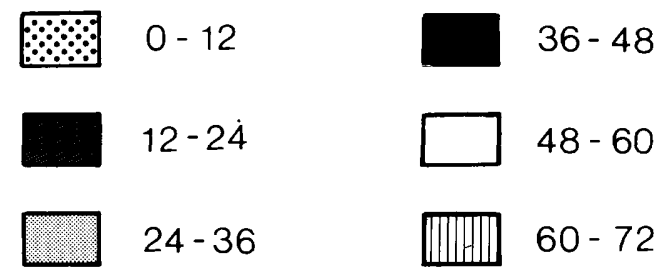

Figure 13.--12-Hour response at Washington, D.C. to a 3-day unit input to Luke, Md. 


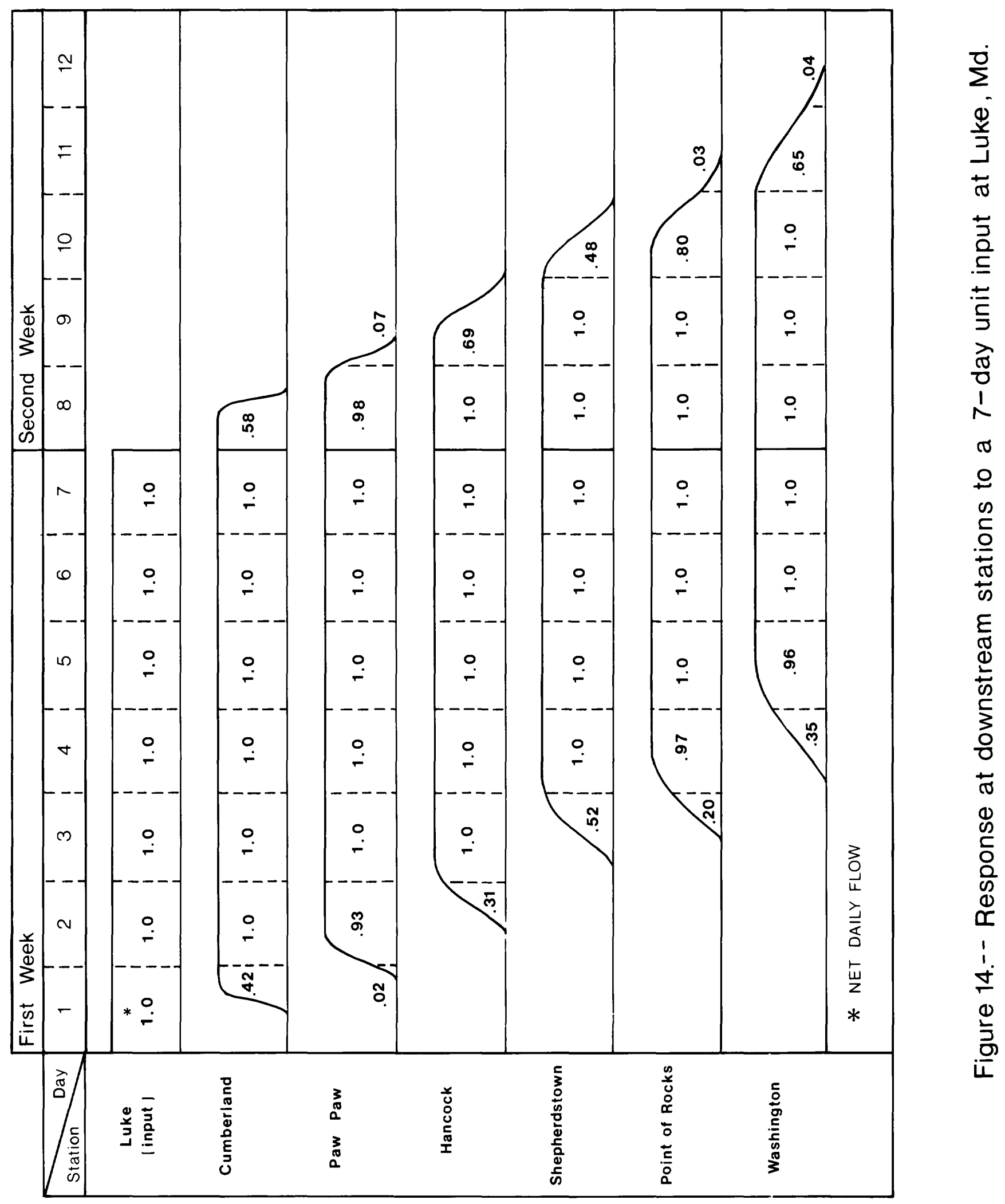




\section{CONCLOS IONS}

A 24-hour sustained reservoir release input at Luke, Md., will result in 35 percent of the flow arriving at Washington, D.C., during the $4 \mathrm{th}$ day after the beginning of the release, followed by 61 percent and 4 percent arriving during the 5 th and $6 \mathrm{th}$ days, respectively. A 7-day sustained reservoir release at Luke will result in 47 percent of the flow arriving at Washington during the 1 st week and 53 percent of the flow arriving during the $2 d$ week.

\section{REFERENCES}

Keefer, T. N., 1974, Desktop computer flow routing: American Society of Civil Engineers Proceedings, Journal of Hydraulics Division, HY7, Proceedings Paper 10669, p. $1047-1058$.

Keefer, T. N., and McQuivey, R. S., 1974, Multiple linearization flow routing model: American Society of Civil Engineers Proceedings, Journal of Hydraulics Division, HY7, Proceedings Paper 10668, p. 1031-1046. Proc. Jour. Hydraulics Div., HY7, Proc. Paper 10668, p. 1031-1046.

Sauer, V. B., 1973, Unit-response method of open-channel flow routing: American Society of Civil Engineers Proceedings, Journal of Hydraulics Division, v.99, no. HY1, p. 179-193. Div., v. 99, no. HY1, p. 179-193.

U.S. Geological Survey, 1981, Water Resources Data for Maryland and Delaware: U.S. Geological Survey Water Data Report, $\mathrm{MD}-\mathrm{DE}-80-1,431 \mathrm{p}$. 